\title{
Overview of Solar Energy for Aquaculture: The Potential and Future Trends
}

\author{
Thi Thu Em Vo ${ }^{1,2,+}$, Hyeyoung Ko ${ }^{3,+}+\mathbb{D}$, Jun-Ho Huh ${ }^{4, *}$ and Namje Park ${ }^{1, *(D)}$ \\ 1 Department of Computer Education, Teachers College, Jeju National University, Jeju-si 63294, Korea; \\ thuempknu@gmail.com \\ 2 Agriculture Department, Phu Yen University, Tuy Hoa 62000, Vietnam \\ 3 Department of Digital Media Design and Applications, Seoul Women's University, Seoul 01797, Korea; \\ kohy@swu.ac.kr \\ 4 Department of Data Science, (National) Korea Maritime and Ocean University, Busan 49112, Korea \\ * Correspondence: 72networks@kmou.ac.kr (J.-H.H.); namjepark@jejunu.ac.kr (N.P.) \\ + Co-first author: There authors contributed equally to this work.
}

Citation: Vo, T.T.E.; Ko, H.; Huh J.-H.; Park, N. Overview of Solar Energy for Aquaculture: The Potential and Future Trends. Energies 2021, 14, 6923. https://doi.org/ $10.3390 /$ en14216923

Academic Editor: Eduardo F. Fernández

Received: 26 August 2021 Accepted: 9 October 2021 Published: 21 October 2021

Publisher's Note: MDPI stays neutral with regard to jurisdictional claims in published maps and institutional affiliations.

Copyright: (c) 2021 by the authors. Licensee MDPI, Basel, Switzerland. This article is an open access article distributed under the terms and conditions of the Creative Commons Attribution (CC BY) license (https:// creativecommons.org/licenses/by/ $4.0 /)$.

\begin{abstract}
The rapid growth of aquaculture production has required a huge power demand, which is estimated to be about $40 \%$ of the total energy cost. However, it is possible to reduce this expense using alternatives such as renewable energy (i.e., solar energy) instead of non-renewable energy. Solar energy is one of the cleanest energy sources and is touted as a potential renewable energy source for the world with benefits such as reducing $\mathrm{CO}_{2}$ emissions, reversing global warming by being eco-friendly, and bringing innovation to sustainable aquaculture and potential cost-efficiency for manufacturing. In this review, we present an overview of using non-renewable and renewable energy sources for aquaculture by reviewing several articles and applications of solar energy at many companies in the world. Moreover, this review shows potential and future trends using solar energy for aquaculture.
\end{abstract}

Keywords: solar energy; renewable energy; aquaculture; future; potential; energy for aquaculture

\section{Introduction}

Aquaculture plays a vital role in the world of food economy, and supplies $43 \%$ of aquatic food for human consumption [1]. There are many aquatic species cultured for commercial use, including fish, crustaceans, mollusks, and others. It supplied about USD 31.94 billion in 2019 with a healthy growth rate of more than $7.1 \%$ for the forecasted period of 2020-2027 [2]. According to the FAO 2020, world aquaculture production reached another record high of 114.5 million tons in live weight in 2018, with a total farmgate sale value of USD 263.6 billion [3].

Mainstream energy sources are used for aquaculture, including oil, diesel, and fossil fuel. The energy cost and matched implications for carbon emission of aquaculture activities are drawing much attention [1]. Tyedmers and Pelletier [4] demonstrated that energy dependence was related to aquaculture production intensity. This depends on the energy input in the production and feed delivery for activities on a farm, which can range from zero up to an estimated $3 \mathrm{kWh} / \mathrm{kg}$. Electricity is generated for land-based farms from the central grid, and diesel and fossil fuels are used on cage-based farms. Based on the intensity of energy for aquaculture by regions, it is showed that Europe and Central Asia has the highest energy intensity with $0.032 \mathrm{TJ} /$ ton, followed by others. The high energy intensity accounts for a large percentage of intensive culture or land-based system [5].

In particular, in the marine aquaculture sector, requirements are in place for energy used for several devices, such as water pumps, aeration systems, light, machines, fridges, ice production, etc. For the offshore culturing sector, energy is supplied for feeder machines, fridges, freezers, devices for staff in terms of culture (lights, televisions, air-condition/fans), aeration system, and others [6]. 
The energy requirement of $60 \%$ the world primary energy from 2002 to 2030 increases annually by $1.7 \%$ per year [2]. According to the organization for Economic Co-operation and Development (OECD), this requires 4.4 tons of oil equivalent annually per capita in developed countries [7] and other developing countries are catching up. Coal, petroleum, and natural gas are fossil fuels in the forms of the present primary sources of energy. The fluctuation of oil price affects the energy sector [6]. The energy industry cannot continue sourcing energy from fossil fuels long-term. However, worldwide energy demand continuously increases. Statistics showed that total global carbon emissions are equal to the total for all previous years, with fossil fuel making up more than $80 \%$ of the primary energy mix for each energy sector over the past 27 years [8].

Within the past 30 years, greenhouse gas (GHG) emissions have been increasing, accounting for $60 \%$ of the total GHG presently. The percentage of carbon dioxide emissions from coal, gas, and oil is estimated to be $44 \%, 20 \%$, and $35 \%$, respectively, together with big amounts of other GHG emissions, such as methane and nitrous dioxide [6]. According to the National Oceanic and Atmospheric Administration (NOAA), $\mathrm{CO}_{2}$ emissions from fossil fuels are the main factors causing climate change [9]. That is a big issue which concerns to the world.

One of the cleanest energy resources is solar energy, which is friendly to the environment and does not cause global warming. It is used instead of oil and coal [10]. Solar energy comes in the form of electromagnetic radiation, emitted from the sun. This electromagnetic radiation is converted into usable thermal or electric power with the aid of mechanical equipment [11]. It is used to provide energy for solar home systems (such as electricity for lighting, televisions, washing machines, and other appliances), cooling systems (air conditioning), and water heater systems with photovoltaic technologies [12]. Currently, there are many countries in the world that have installed solar power systems as alternative energy, such as China, Taiwan, South Africa, United States, Australia, etc. [13].

Presently, solar photovoltaic (PV) modules and concentrated solar power (CSP) are the two kinds of main solar technologies. The principal of PV operation is that the PV cell absorbs sunlight and then transforms it into electricity by the movement of atoms. However, CSP focuses the sunlight onto a mirror and then transfers it into steam to move a turbine, which generates electricity [14].

PV (photovoltaic) is made by several PV devices. A PV device is considered to be a PV cell, which can transform solar power into electricity using semiconducting materials. With the interconnection among cells, the PV module is formed. The PV system has several parts, including inverters, batteries, electrical components, and mounting systems. Each PV system is linked to another to increase the capacity of electricity from a few Watts to $100 \mathrm{~kW}[13,15,16]$. There are many different kinds of PV modules recently produced, based on PV cell semiconductor materials. Each PV module has advantages and disadvantages for applications. Therefore, the kind of PV module is chosen depending on the target application $[17,18]$. Many kinds of PV systems have been recently used, such as rooftop, canal top, offshore, and floating PV systems [19].

Concentrated solar power (CSP) technologies can produce electricity through concentrating sun radiation to heat a steam turbine, which can generate electric power. Recently, several CSP technologies have been improved. For example, a transfer oil or circulating molten salt is circulated through the steel pipe, where it is heated [14]; circulating molten salt is an effective material because it can be stored several days before generation into electricity. That means electricity can be generated in days without sunlight or during nighttime [20,21]. Generally, there are three different CSP technologies to heat the medium have been used recently. These are trough systems, power tower systems, and engine systems [22,23].

Solar energy is also one of the energy sources for aquaculture in many countries in the world, including China, America, Canada, Germany, Korea, and Vietnam. It is applied for the culturing of many aquatic species, including fresh water, seawater. For instance, photovoltaic power is used for the aeration of fishponds, and new energy technologies are 
applied for marine fish hatchery production [24-31]. Moreover, solar-generated electricity provides off-grid aquaculture potential [31].

In this paper, we present the status of energy used in cultivating different aquatic species in intensive, semi-intensive, and extensive systems with various culture-raising technologies in several countries. From that point, we survey the status of solar energy used in aquaculture. From this, we offer an overview of potential and future trends to develop more renewable energy for aquaculture in a sustainable way. A brief diagram of this review is presented in Figure 1. The strategy of this review is presented as follows: (1) the status of energy used in aquaculture; (2) the status of solar energy for aquaculture; (3) the potential of solar energy for aquaculture; (4) the future of solar energy for aquaculture.

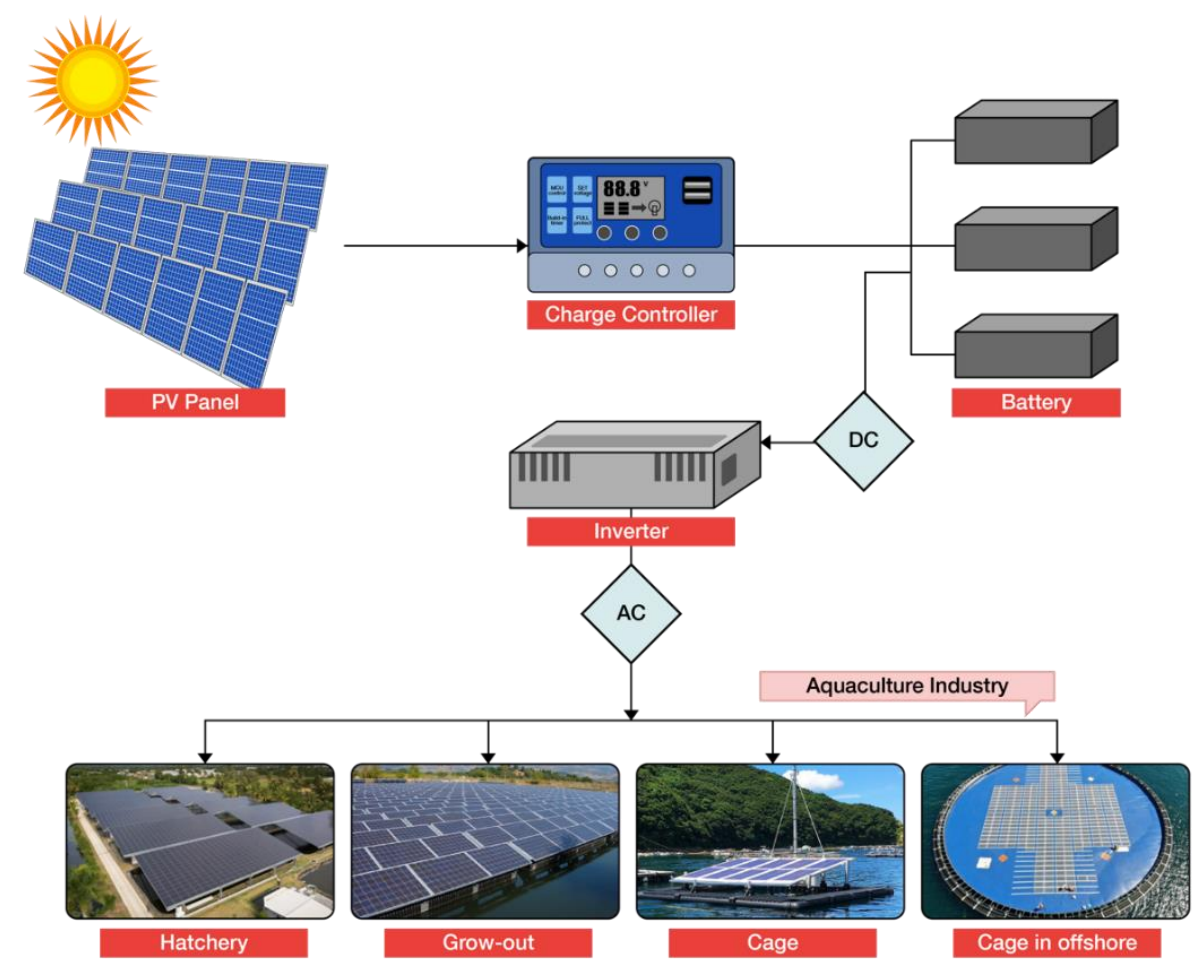

Figure 1. Applications solar power in aquaculture.

\section{Overview of Solar Energy for Aquaculture}

\subsection{Status of Energy Used in Aquaculture}

The more that aquaculture production has dramatically increased, the more intensively energy has been consumed, especially from non-renewable sources. As the price of energy increases, it strongly impacts on aquaculture industry activities, which may reduce food security at the local, regional, and global level [18].

In aquaculture, energy intensity depends on cultured species, scale, system, technology, production, and local conditions [32,33]. Many studies have been conducted to determine the energy intensity used in different culture systems with various aquatic species. Toner and Mathies [34] conducted an experiment to estimate the energy consumption for three inland aquaculture sites-a farm for Pacific oyster, a farm for rainbow trout, and a farm for marine fish grown under recirculation. The results showed that energy production for a Pacific oyster farm is equal to energy consumption for a family. On the other hand, the most power is used for purification systems, and then the pond aerator with 33.6 kilowatt-hours $(\mathrm{kWh}) /$ week, and $15.4 \mathrm{kWh}$ /week, respectively. The most power is used for the aeration system $(23.8 \mathrm{kWh} /$ week) and recirculation system (13.440 kWh/week) in the farm for rainbow trout and for marine fish, respectively.

Aquatera [35] took account of the energy consumption and sites for aquaculture. This research was conducted for a freshwater aquaculture system; however, the obtained results 
can be used as a good sample for other water resources. There was discussion to find out and supply input techniques for an offshore aquaculture position using a combination of electrical and physical elements as well as others, including energy storage and backup to account for the fluctuation of wave resources. More detail can be found in a review which conducted by Fiander et al. [36]. The energy demand cycle lasts between two and three years in a fish farm. It depends on production biomass and the production cycle stage [36]. The most energy consumption in a fish farm is not related to marine energy resources according to season. When choosing the position for aquaculture, the ability to supply energy in each season should be considered, as it may decline somewhat as a consequence of a combination between marine energy resources and energy storage systems.

For more detail, Table 1 shows the use of energy in aquaculture for more than 10 years, year-round. The table shows that most studies were conducted in a semi-intensive and intensive system. Re-circulating aquaculture system (RAS) had higher energy consumption than others. Ayer and Tyedmers [37] investigated the intensity of the salmon culture system with net-pen, flow-through, land-based, and RAS techniques. Pelletier et al. [38] also studied the energy input in intensive systems in different countries for salmon production. Pelletier and Tyedmers [39] also conducted an experiment to consume energy for intensive cultivated tilapia in land-based farms. Heeb and Wyss [40] studied energy consumption in RAS for tilapia production. Costa-Pierce [41] researched salmon, oysters, and shrimp in different culture systems.

Table 1. Energy used in aquaculture.

\begin{tabular}{|c|c|c|c|c|}
\hline References & Species & $\begin{array}{l}\text { System } \\
\text { Intensity }\end{array}$ & Culture Technology & $\begin{array}{l}\text { Energy Intensive } \\
\text { (MJ/kg Production) }\end{array}$ \\
\hline \multirow{7}{*}{$\begin{array}{c}\text { Ayer \& } \\
\text { Tyedmers } \\
\text { [37] }\end{array}$} & Salmon & Intensive & Net-pen, marine & 27 \\
\hline & Salmon & Intensive & Flow-through, land-based saltwater & 98 \\
\hline & Salmon & Intensive & Re-circulating, land-based freshwater & 353 \\
\hline & Salmon & Intensive & RAS & 92 \\
\hline & Salmon & Semi-intensive & Flow-through & 48 \\
\hline & Salmon & Semi-intensive & Floating bag system & 6 \\
\hline & salmon & Semi-intensive & Net pen & 3 \\
\hline \multirow{3}{*}{$\begin{array}{l}\text { Pelletier } \\
\text { et al. [38] }\end{array}$} & Salmon & Intensive & Canada & 31 \\
\hline & Salmon & Intensive & UK & 48 \\
\hline & Salmon & Intensive & Norway & 26 \\
\hline \multirow{2}{*}{$\begin{array}{c}\text { Heeb \& } \\
\text { Wyss [39] }\end{array}$} & Tilapia & Intensive & RAS & 772 \\
\hline & Tilapia & Intensive & RAS & 570 \\
\hline $\begin{array}{c}\text { Eding et al. } \\
\text { [42] }\end{array}$ & Tilapia & Intensive & RAS & 19 \\
\hline \multirow{3}{*}{$\begin{array}{c}\text { Aubin et al. } \\
\text { [43] }\end{array}$} & Turbot & Intensive & RAS & 281 \\
\hline & Trout & Intensive & Flow-through Raceway & 68 \\
\hline & Seabass & Intensive & Cage & 49 \\
\hline \multirow{6}{*}{$\begin{array}{l}\text { Gál et al. } \\
\text { [44] }\end{array}$} & Catfish, tilapia, carp, mussel & Intensive & Pond & 78 \\
\hline & Catfish, tilapia, carp & Intensive & Pond & 37 \\
\hline & Catfish & Intensive & Pond & 68 \\
\hline & Catfish, tilapia, carp, mussel & Extensive & Pond & 30 \\
\hline & Catfish, tilapia, carp & Extensive & Pond & 27 \\
\hline & Catfish & Extensive & Pond & 32 \\
\hline
\end{tabular}


Table 1. Cont.

\begin{tabular}{|c|c|c|c|c|}
\hline References & Species & $\begin{array}{l}\text { System } \\
\text { Intensity }\end{array}$ & Culture Technology & $\begin{array}{l}\text { Energy Intensive } \\
\text { (MJ/kg Production) }\end{array}$ \\
\hline & Catfish, tilapia, carp, mussel & Extensive & Pond & 10 \\
\hline & Catfish, tilapia, carp & Extensive & Pond & 9 \\
\hline & Catfish & Extensive & Pond & 10 \\
\hline & Carp & Semi-intensive & Pond & 23 \\
\hline & Carp & Semi-intensive & Pond & 48 \\
\hline $\begin{array}{c}\text { Pelletier and } \\
\text { Tyedmers } \\
\text { [39] }\end{array}$ & Tilapia & Intensive & Lake-based & 18 \\
\hline \multirow{9}{*}{$\begin{array}{c}\text { Costa- } \\
\text { Pierce, } \\
{[41]}\end{array}$} & Salmon & $\mathrm{n} / \mathrm{a}$ & Tanks & 45 \\
\hline & Oysters & intensive & Cage & 586 \\
\hline & Shrimp & Semi-intensive & Pond & 40 \\
\hline & Catfish & $\mathrm{n} / \mathrm{a}$ & Pond & 84 \\
\hline & Tilapia & Semi-intensive & $\mathrm{Na}$ & 60 \\
\hline & Mussel & $\mathrm{n} / \mathrm{a}$ & Longline & 1 \\
\hline & Trout & intensive & Cage & 40 \\
\hline & Tilapia & Semi-intensive & Pond & 40 \\
\hline & Carp & intensive & Pond & 40 \\
\hline \multirow{2}{*}{$\begin{array}{l}\text { Cao et al. } \\
\text { [45] }\end{array}$} & \multirow{2}{*}{$\begin{array}{l}\text { White-leg shrimp } \\
\text { Litopenaeus vannamei }\end{array}$} & Intensive & \multirow{2}{*}{ Ponds } & 62 \\
\hline & & Semi-intensive & & 34 \\
\hline $\begin{array}{c}\text { Iribarren } \\
\text { [46] }\end{array}$ & $\begin{array}{c}\text { Galician mussels (Mytilus } \\
\text { galloprovincialis) }\end{array}$ & Extensive & Rafts & 3 \\
\hline $\begin{array}{l}\text { Winther } \\
\text { et al. [47] }\end{array}$ & $\begin{array}{c}\text { Blue mussels (Mytilus } \\
\text { edulis) }\end{array}$ & Extensive & Longline & 3 \\
\hline \multirow{2}{*}{$\begin{array}{l}\text { Meyhoff Fry } \\
\text { [48]. }\end{array}$} & Blue mussels (Mytilus eduli) & Extensive & Longline & 1 \\
\hline & Oysters & Extensive & Bag and trestle & 4 \\
\hline $\begin{array}{l}\text { Kim et al. } \\
\text { [49] }\end{array}$ & Tilapia & Semi-intensive & RAS (aquaponics) & 16 \\
\hline $\begin{array}{l}\text { Kim et al. } \\
\text { [49] }\end{array}$ & Red drum & Intensive & RAS & 81 \\
\hline $\begin{array}{l}\text { Boxman } \\
\text { et al. [50] }\end{array}$ & Red drum & Semi-intensive & RAS (aquaponics) & 25 \\
\hline
\end{tabular}

\subsection{Status of Solar Energy Used in Aquaculture}

Presently, using solar energy in aquaculture has been increasing because of the benefits of low operation cost, long life-cycle, environmental friendliness, no $\mathrm{CO}_{2}$ emissions, and low soil contamination [51]. There are several applications of solar energy in aquaculture $[11,52]$, such as solar power generation, solar aerators to oxygenate the water, solar feed dispensers, solar pumps, and solar water heat systems [53].

The aeration of water when rearing aquatic species, especially white-leg shrimp and fish in intensive systems, increases oxygen levels, which contributes significantly to productivity. Applebaum et al. [24] constructed an aeration system using photovoltaic power to generate electricity for driving a paddle wheel to maintain a dissolved oxygen level for fish in ponds. It was the first photovoltaic aeration system in Israel. They built the system with a photovoltaic array, electric motor, gear system (a 13:1 ratio with a paddlewheel speed of $144 \mathrm{rpm}$ ), paddle wheel, battery, and charge controller. They obtained 
results in which the dissolved oxygen level was kept safe in the fishpond ( 2 ppm or greater). This system demonstrated that the operation of an aeration system at night could reduce the required size of the photovoltaic system, enabling an economical design. Another aeration system was designed by Prasetyaningsari et al. [54] to supply electricity for an aeration system in fishponds in Indonesia. They used a solar PV of $1 \mathrm{~kW}, 8$ batteries of $200 \mathrm{Ah}$ as an electric storage container, and an inverter at $0.2 \mathrm{~kW}$. The harvested electricity supplied not only aeration but also indoor and outdoor lighting. The result showed that COE (cost of energy) was about $0.769 \$ / \mathrm{kWh}$, which is economically most effective. Tanveer and Mayilsamy [23] proposed a solar-powered aeration system for aquaculture farms. The constructed system included PV solar panels (up to a maximum of $100 \mathrm{~kW}$ ), DC converter (convert to $120 \mathrm{VAC}$ or $240 \mathrm{VAC}$ ), solar batteries, an aerator (paddle wheel or spiral type), and a power meter. The Figure 1 shows how the PV panel absorbs solar power to generate electricity. The inverter is a tool to convert direct current (DC) from the battery to alternating current (AC). The battery is the tool to store the electricity in the form of a chemical reaction. A power meter is used to check the power consumed by the system. The whole system is shown in Figure 2. This is an efficient approach for farmers, from whom there is demand to apply this system for their farms.

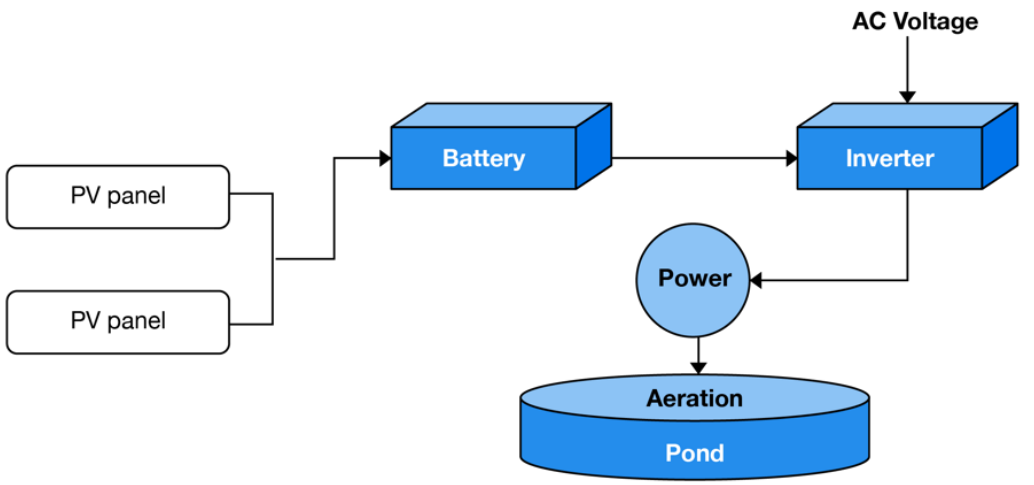

Figure 2. Solar-powered aeration system in an aquaculture pond.

Liu et al. [55] designed a machine to regulate and control water quality in freshwater fishponds using solar power as the main energy for operation. The machine can walk on water to collect the sludge from the bottom of ponds. The power supplied for the system came from two photovoltaic panels $(1.6 \mathrm{~m} \times 0.8 \mathrm{~m})$, a power output of $24 \mathrm{~V}$, and a DC motor. The system is shown in Figure 3 [11,52].
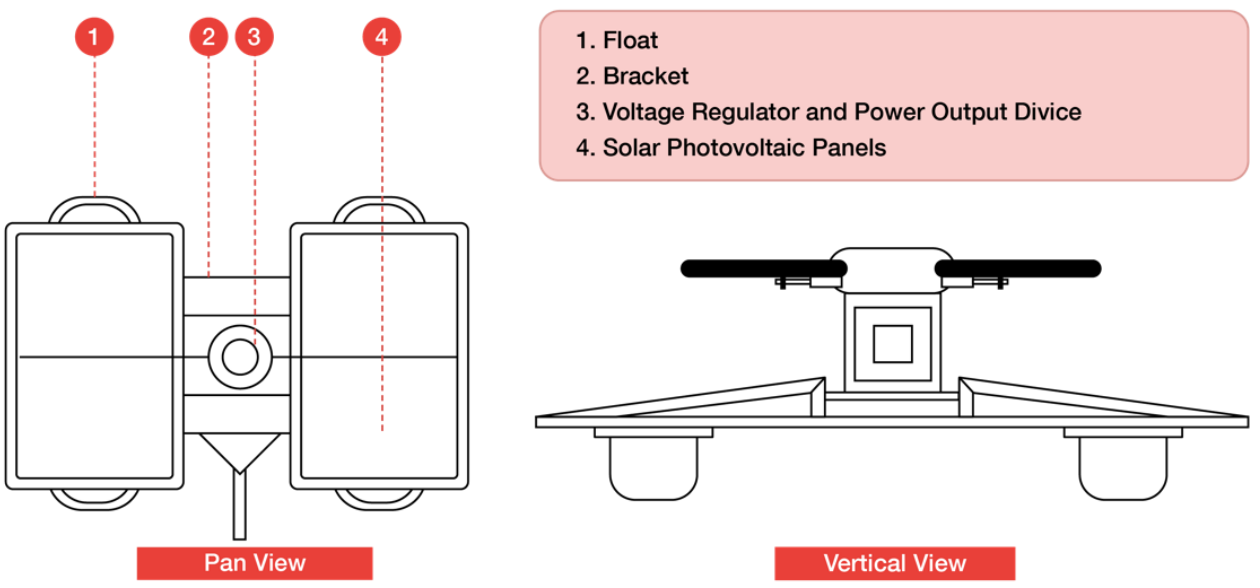

Figure 3. Walking machine.

The light controller, lifting device, walking mechanism, and stabilizer are provided by a total of $250 \mathrm{~W}$ of total solar power. The designed machines on water have a capacity of 
$13,000 \mathrm{Lx}$ of illumination and $0.02-0.03 \mathrm{~m} / \mathrm{s}$ of its stable speed on the water. The sedimentlifting device runs at $0.13-0.35 \mathrm{~m} / \mathrm{s}$, and water delivery capacity is $110-208 \mathrm{~m}^{3} / \mathrm{h}$ for 13,000-52,500 Lx of an illumination. The machine may work well in ponds at different water depths, with a distance of sediment-lifting device to the bottom being $0.5-2 \mathrm{~m}$ to $10-15 \mathrm{~cm}$. The machine's efficiency of operation can reach $80 \%$.

Hendarti et al. [56] studied the required illuminance, floating net cage structure, and types of solar panels that affect the growth of grouper. The results showed that 200 and 1150 lux is the suitable illuminance range to grow grouper in a cage. In addition, a transparent solar cell film is the most appropriate PV panel, compared to a panel with transparent solar cells and a panel that is fully covered with solar cells (Figure 4).

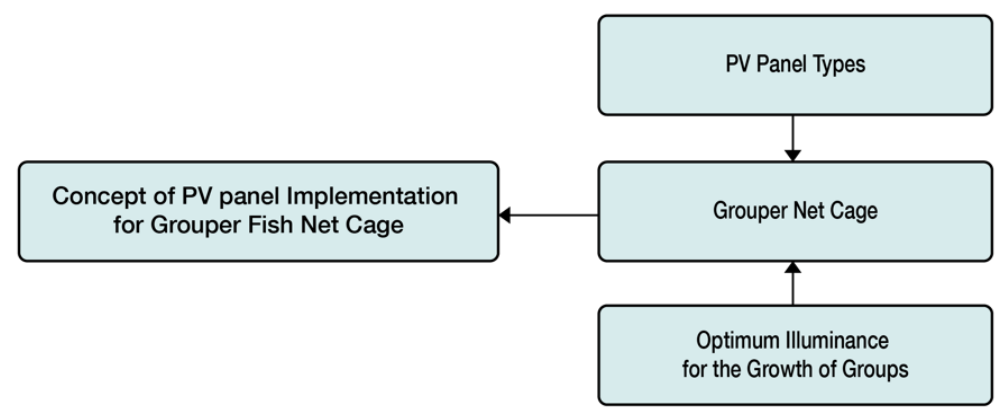

Figure 4. Experiment for choosing a suitable PV panel for grouper growth in a net cage.

Solar power has recently increased in aquaculture in developed countries as well as in developing countries. Kirihara et al. [57] studied the work being done to adapt renewable energy for horse mackerel and create a sea cucumber cultivation system in Japan. The energy in this system can be maintained a cultivating environment for fish and sea cucumber to live well in a suitable environment. The proposed energy system includes a solar panel, small wind-power generation, and batteries. The energy enables an air supply pump to maintain the water quality in cultivation systems. The brief system is presented in Figure 5 with a monitoring and preservation system, in which batteries are connected to a small wind-power turbine and solar panels to provide electricity for an air pump and other tools for aquatic species and to monitor the water quality in the fishing port.

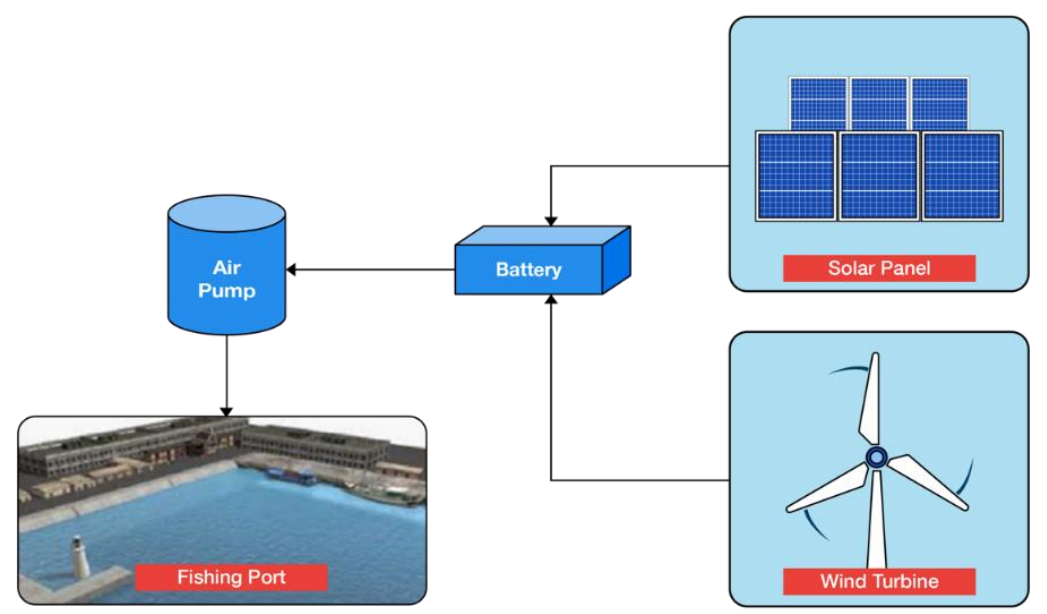

Figure 5. Concept of system in a fishing port.

Nguyen et al. [58,59] obtained economical production and reduced GHG emissions in a sustainable energy model for shrimp farms. Solar energy is used to operate the aeration system in shrimp ponds. The system built on shrimp ponds includes small wind turbines, photovoltaic arrays, a battery, an alkaline electrolyzer, PEM (proton-exchange 8888) a fuel 
cell, storage systems for oxygen and hydrogen, a micro-bubble generation system, a water treatment system, and an associated load at the shrimp farm (Figure 6).

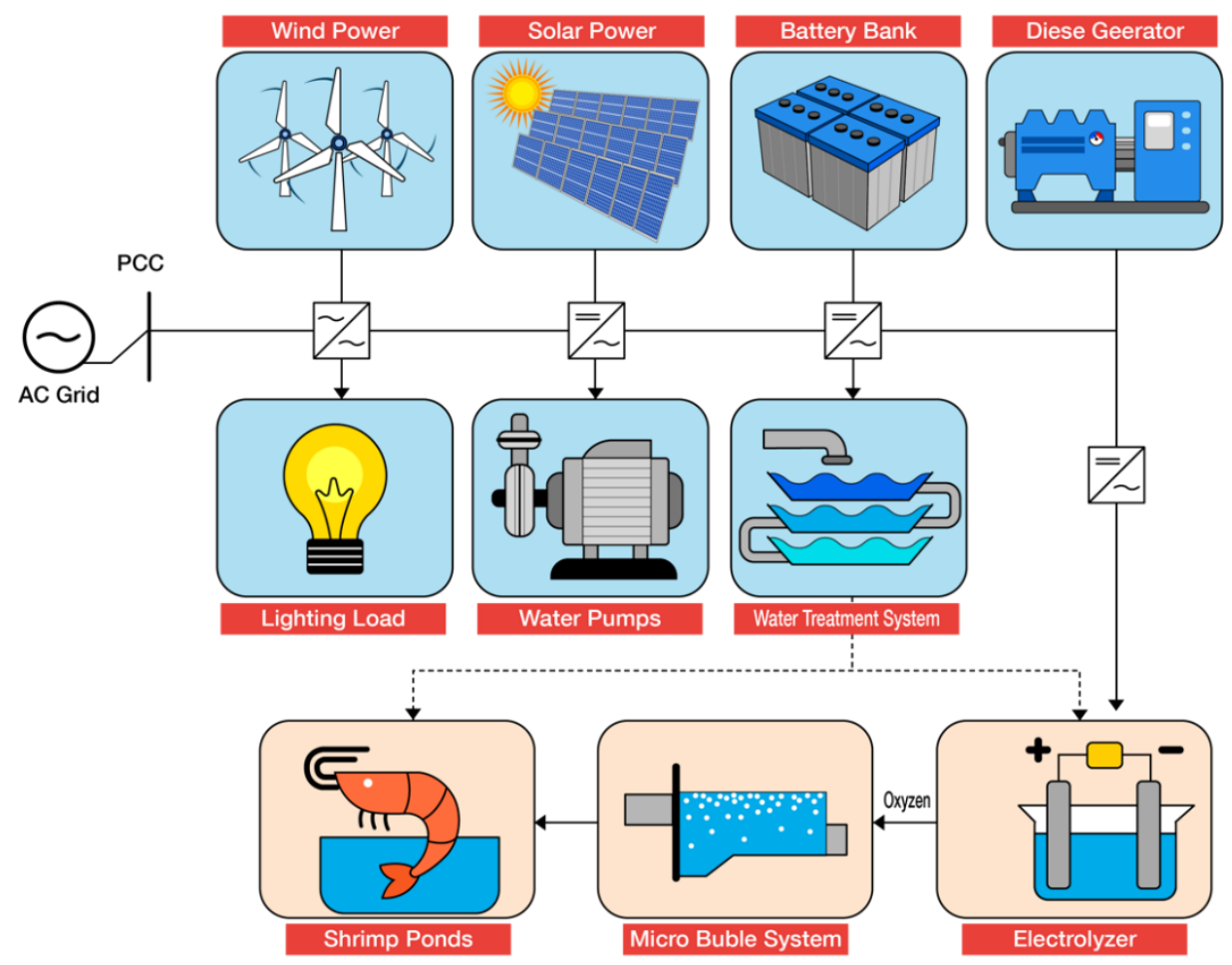

Figure 6. Designed system applied to shrimp ponds.

Electricity is generated from wind turbines, solar panels, a battery bank for energy storage, a diesel generator, and grid-connected operation modes. The electricity is supplied for lighting, water pumps, wastewater treatment systems, and alkaline electrolyzer. The alkaline electrolyzer provides pure oxygen as a micro-bubble generation system before feeding a shrimp pond. The results showed that a wind system and PV arrays are the suitable renewable energy sources for improving the DO concentration in a cultured pond, saving power costs, reducing operation cost and decreasing the amount of $\mathrm{CO}_{2}$ emissions.

Tous-Zamora et al. [60] proposed an aquaponic system for a single family using solar power to introduce sustainable farming in underdeveloped countries. The solar power includes PV panels, a PC-AC battery system, and an inverter. The generated power consumption was enough for 5 pumps, an aerator, a UV filter, and LED lights. The total generated power was $24.204 \mathrm{Wh}$ /day. The system could operate 7 days a week, $24 \mathrm{~h}$ a day, with estimated periods without sunshine. The RAS system (Figure 7) uses solar power as its main energy and is designed by Dedy Kurniawan [61]. The RAS consists of a culture tank, filter, biofilter, aeration system, and recirculation pump. The electric power required to operate this system comes from solar energy with solar cells.

Babiyola and Selva [62] built a system used for aquaculture including a way to develop solar photovoltaic polycrystalline solar panels covering an area of $8000 \mathrm{sq}$. ft. This type of panel generates pure direct power that generates electricity for the aquaculture field. A DC-to-AC converter and dual-input inverter was combined into a fuse box. Using an inverter output connected to the export-import meter line, this renewable energy output is directly connected to the distribution power supply lines for the aquaculture sector and reduces fossil-fuel consumption. In addition, the solar grid power plant system was used to generate electrical energy on site. The on-the-grid solar power plant consists of solar PV modules, one or more inverters, and grid connection equipment. Here, solar PV modules are used to generate DC electrical energy, and the grid tie inverter is used to convert DC electrical energy to AC electrical energy (Figure 8) [62]. 


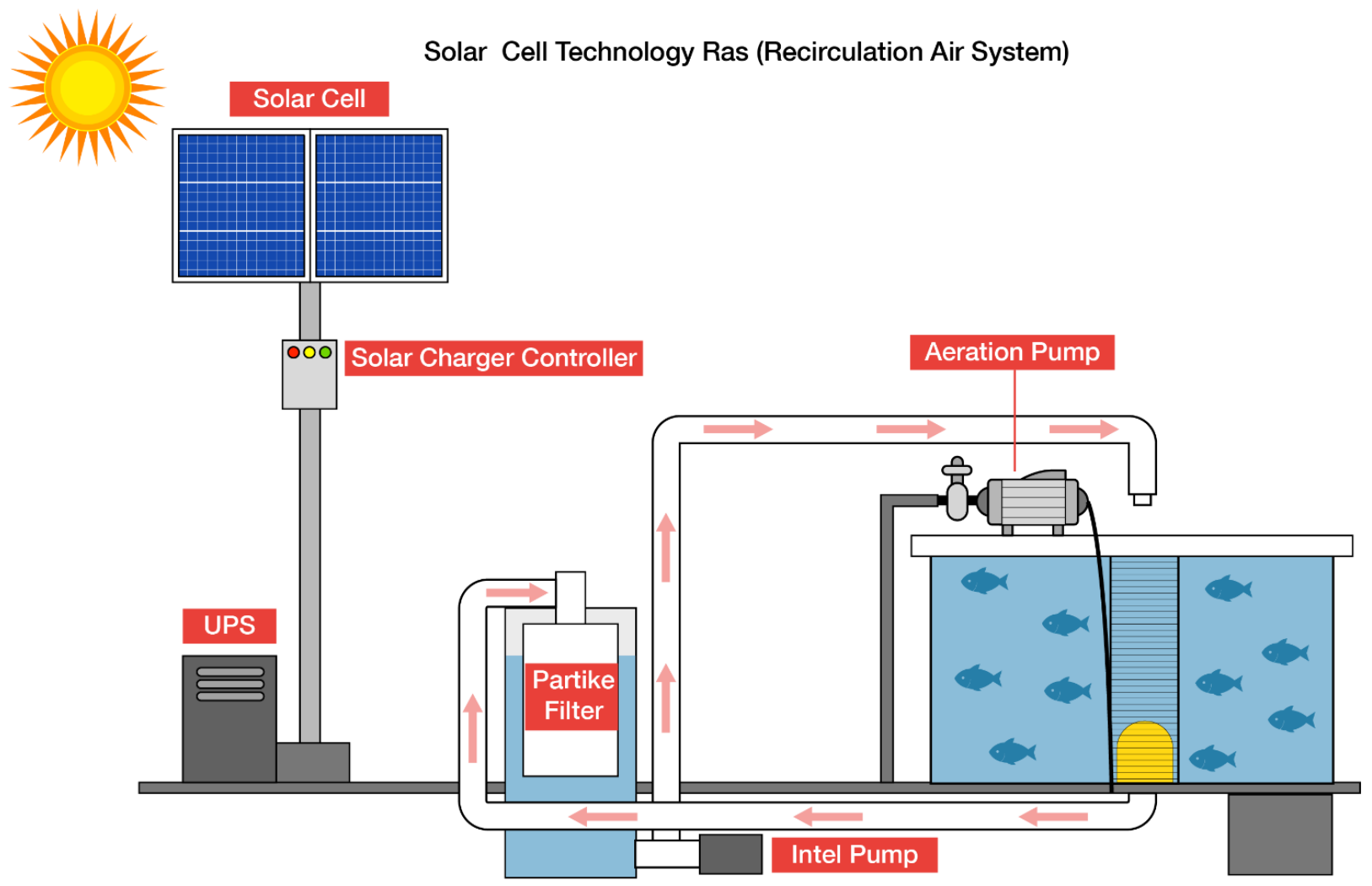

Figure 7. The solar cell recirculated aquaculture system.

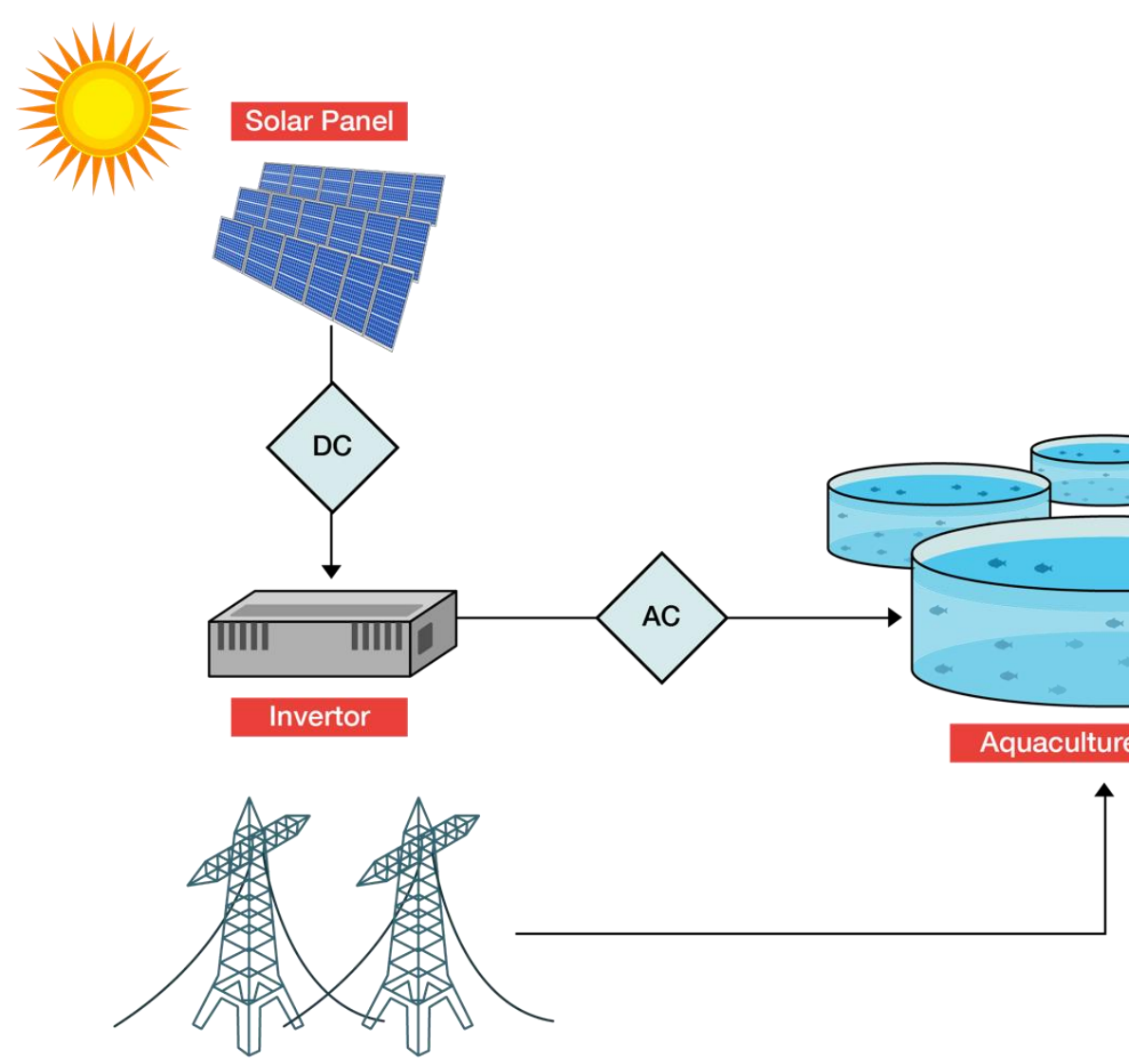

Grid Power

Figure 8. Schema of energy for aquaculture. 
Cornejo-Ponce et al. [63] proposed a system for culturing shrimp in a river using solar power. There is a trend to develop aquaculture in a sustainable way in Camarones, a village in Chile with a recirculation aquaculture system. The system includes three main parts-solar power treatment plants, an aquatic recirculation system, and photovoltaic cells. The photovoltaic plant generates electricity from solar power and distributes electricity for the integrated aquatic recirculation system. An estimated $9 \mathrm{~m}^{3}$ per day of treated water and $1 \mathrm{~m}^{3}$ per day of liquid waste were produced by the solar water treatment plant system. For the first cycle, the treated water supplied trout and shrimp ponds, and then the water began flowing and passing through a filtration system. All the system and its directions are shown in Figure 9 [63]. One of the main goals of this study was to install a solar power system to provide energy generation for all equipment on a farm.

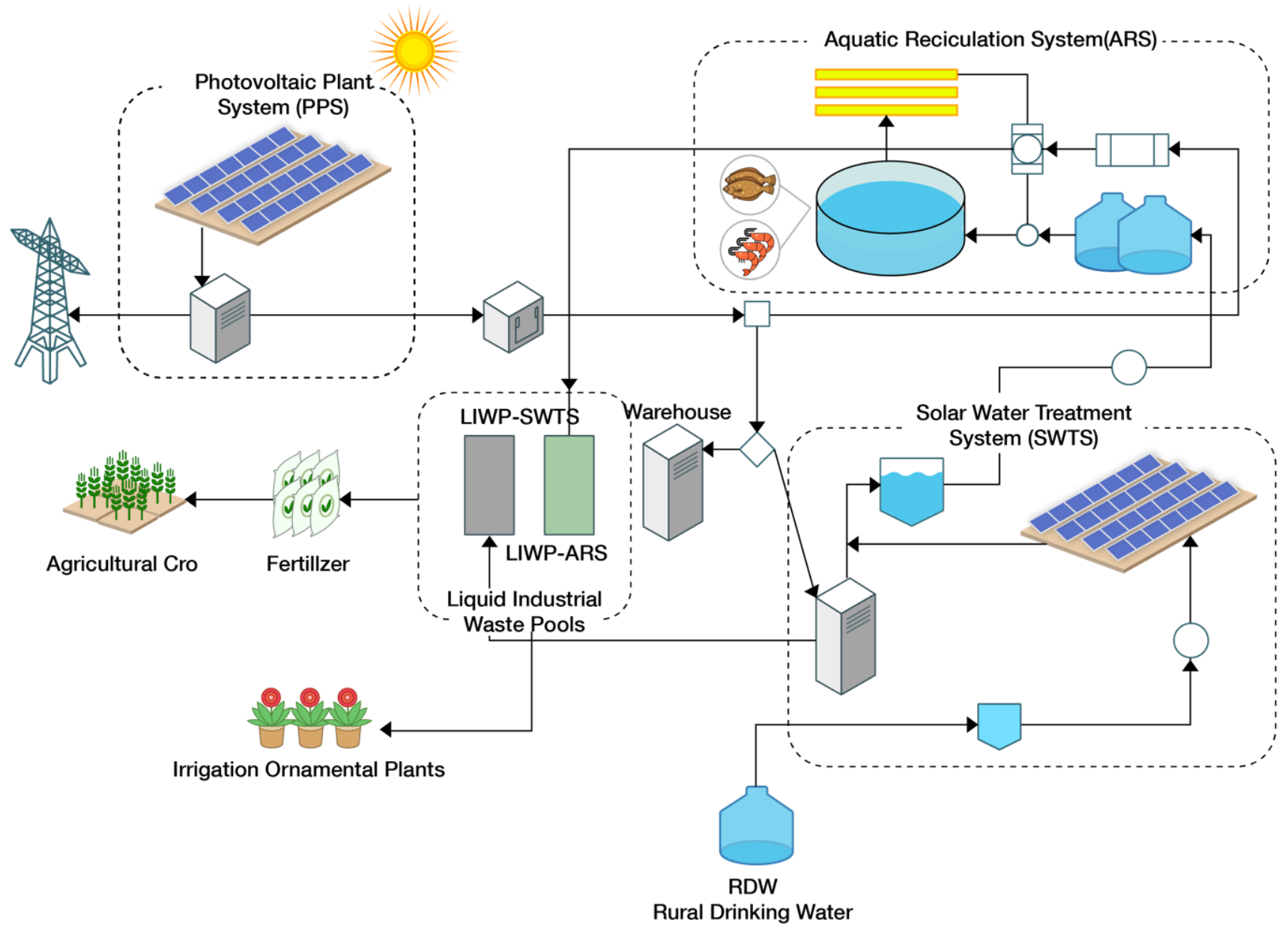

Figure 9. Integrated aquaculture recirculation system plant.

Lately, solar power has become the generated power source of choice for the aquaculture industry. Many fisheries, private companies, and aquaculturalists have applied solar power to generate electricity for their farms in many countries. Energy is the costliest factor in aquaculture, so solar power is an excellent solution to solve this problem and boost sustainability. However, there are many challenges for using solar power according to many aquaculture companies [64].

A solar power station of $200 \mathrm{MW}$ capacity has been deployed for several fish farms in eastern China's Cixi City, Zhejiang Province. The biggest PV solar plant, which has about 300 hectares of solar panels, can supply electricity for 100,000 households. The fishery expects to achieve annually about RMB 240 million from the fish farms when there is a combination between solar power and national grid. It must be sure to maintain proper space between solar panels to ensure enough supply of sunlight for the development of 
fish in culture systems. In addition, using PV panels to cover the culture systems (pond, tank) makes for shade that can gradually reduce the water temperature on a hot day. This is helpful for fish growth [65].

In Taiwan, solar panels have been installed above a giant 60-hectare fishpond. Under the prerequisite that the solar photovoltaic cells do not change the landscape, building such a facility equipped with AI technologies on a large fishpond to co-develop fisheries and electricity serves government policy and will create a niche for fish farming, green energy, and a clean environment [66].

Vietnam is one of the biggest shrimp exporters in the world, and farms are usually located in remote off-grid locations. Aquaculturalists must operate their culture activities using expensive diesel power generation, partially or fully. Moreover, national electricity is not enough to supply all farms. Therefore, the Frauhofer Institute for Solar Energy supports PV's potential to solve the energy demand issues of land-based aquaculture systems. The project is designed to explain the dual technical and commercial feasibility of solar power generation in commercial aquaculture. The Frauhofer Institute announced that a one-megawatt pilot plant may cut $\mathrm{CO}_{2}$ emissions by about 15,000 metric tons each year and cut water consumption by $75 \%$ compared to a conventional shrimp farm. In addition, PV panels cover the water's surface, which will help reduce water evaporation and protect aquatic species from predatory birds [67]. Moreover, in the Bac Lieu and Ca Mau Provinces, with 5 hectares and 0.3 hectare of commercial shrimp ponds, respectively, the solar-constructed systems, which include two photovoltaics (85 Watts each) with 2 batteries of 12 V DC, supplied energy for a 120-Watt aeration, lights, a transformer, and a pump. Figure 10 shows model of PV panels applied in Vietnam [67].

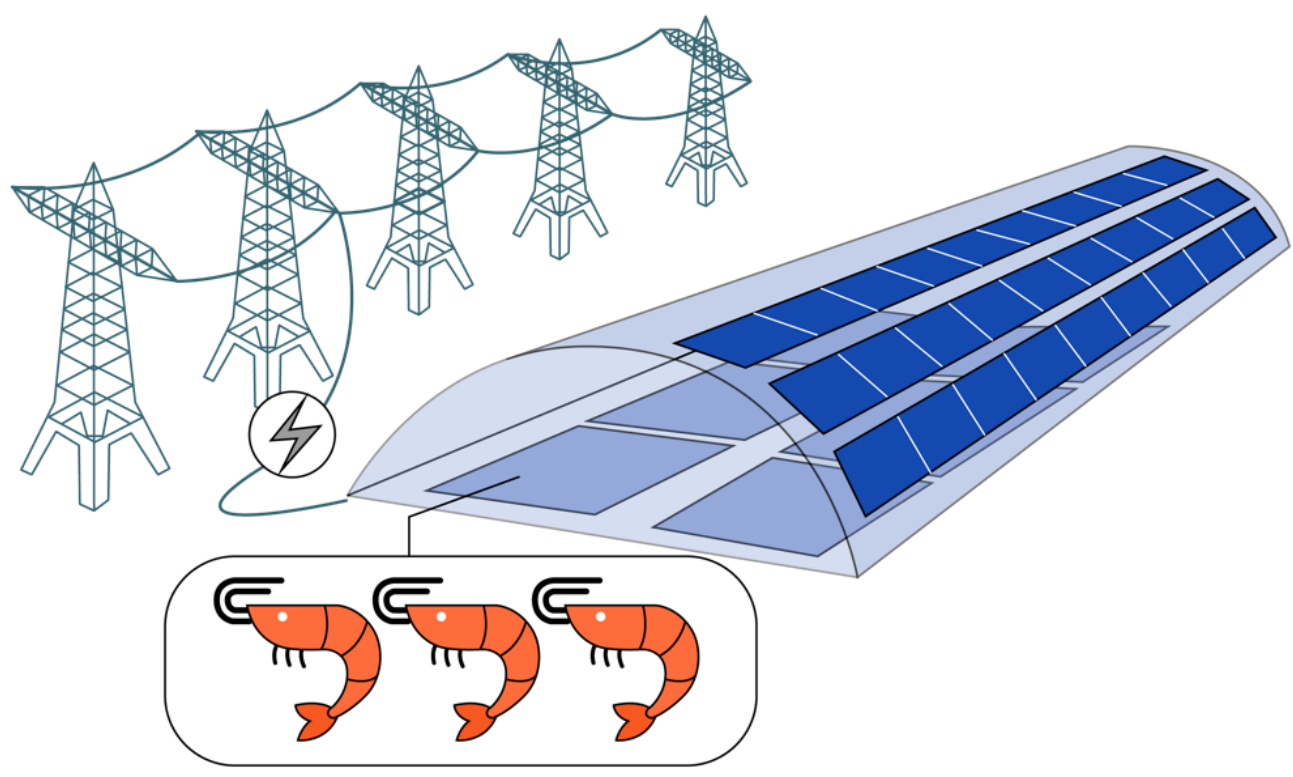

Figure 10. A model of PV panels applied in Vietnam.

In Bangladesh, solar-power-driven aeration and circular water current systems are used in shrimp farming. They developed aeration technology power to maintain a dissolved oxygen level of 5-6 ppm and to create water circulation to solve problems common to cultured shrimp in a semi-intensive area. For instance, low productivity from shrimp deaths (mortality rate of 60-80\%) resulted from insufficient dissolved oxygen, with a lack of grid electricity in most of the shrimp-producing areas, which consist of 200 semi-intensive shrimp farms with 2000 operating ponds [68].

In Canada, D'Eon Oyster Co. solved their problem in the oyster culture system after they adopted a solar-powered system. Since the location in which they cultured oysters has fluctuating tides and long-lasting low tide, it is hard to collect cultured oysters. At the same time, much human labor is required for harvesting and transportation stages. In 
cases of low tide, the workers spend much time waiting to do other processes. To solve the above problems during culture oysters, solar power has been deployed with 8 PV panels and an energy storage system. The generated electricity can supply power to install more equipment/machinery (a tumbler and a shaker table) which reduce human force. The battery capacity can store enough energy for 3 days without sunlight (Figure 11) [64].

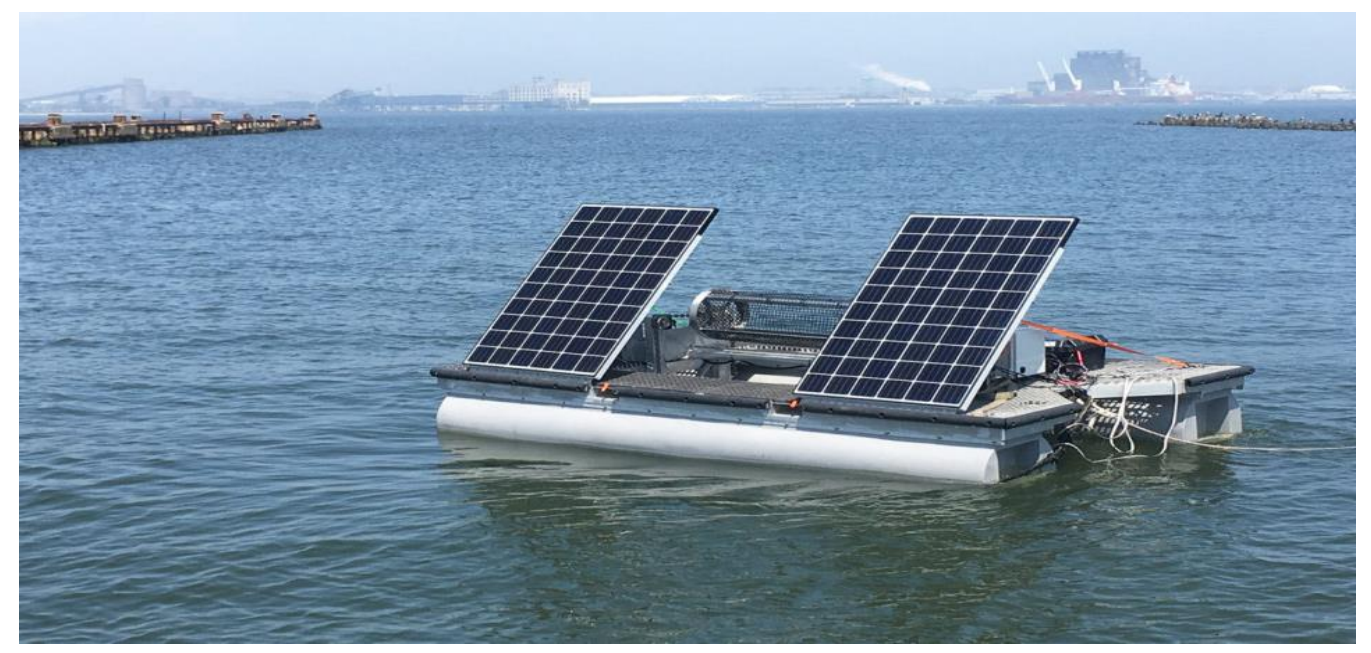

Figure 11. Photo courtesy of Solar Oysters.

In Egypt, because the cost of fuel and maintenance has been increasing, solar power has been seriously considered and can be used for aquaculture due to its advantages [69].

\subsection{The Potential of Solar Energy Used in Aquaculture}

Solar energy has the most potential for renewable energy among natural resources since it comes from thermal radiation emitted by the sun [70]. According to Mahesh and Shoba Jasmin [71] and Liu et al. [72], solar radiation produces about $1000 \mathrm{~W} / \mathrm{m}^{2}$ within a few hours in clear conditions at noon in full sunlight. Solar energy's potential output ranges from 1575 to 49,837 EJ/ year. Furthermore, 450 billion kWh/year of renewable energy could be produced by 2030, and an estimated 4572 TWh of electricity generated by PV would be reached by 2050 [73-75].

At the same time, the market of PV solar is $12 \%$ (the equivalent $115 \mathrm{GW}$ ) of a total of 627 GW. In Honduras, solar power plants gained $10.7 \%$ of total solar energy generation, which is comparable to many other countries such as Italy $(8.6 \%)$, Greece $(8.3 \%)$, Germany $(8.2 \%)$, and Chile $(8.1 \%)$. It is possible to match the world energy demand of $2.8 \%$ of global electricity generation by the end of the year. Currently, Africa and Asia have continuously increasing PV solar plant projects [76].

In particular, the potential for solar photovoltaic aquaculture or aquavoltaic ecology was found to be promising [31]. Solar photovoltaic (PV) power generation is growing fast around the world, and is expected to account for $30-50 \%$ of electricity generation by 2050 [77]. According to Solangi et al. [10], summarized in Figure 12, by 2030, with expected development and installation of PV electricity in many countries such as the US, Europe, and Japan, it is an optimal future power source for aquaculture.

In addition, several countries all over the world have set public policies to develop their renewable energy sources, specifically solar energy. This is an immense opportunity for the use solar energy in agriculture as well as aquaculture.

For instance, solar power could account for 10\% of the US's power needs by 2025. A published research report by Clean Edge as well as by the nonprofit Co-op America projects that nearly $2 \%$ of the nation's electricity was derived from concentrated solar power systems, while solar photovoltaic systems would supply over $8 \%$ of the nation's electricity. These figures amount to nearly 50.000 MW of solar photovoltaic systems and more than 
$6600 \mathrm{MW}$ of concentrated solar power [78]. In Canada, the government is keen on the expansion of the distributed generation of renewable energy, especially roof-mounted photovoltaics [79]. Ontario is one of the most important regions for the development of solar energy applications, including a potential $30 \mathrm{GW}$ from viable solar areas on rooftops and over $90 \mathrm{GW}$ from land-based solar farms on marginal farms [80]. Although Germany is one of the lead markets for solar power in the world, it still accounts for a small amount, with $4 \%$ of total electricity generated from renewable sources. Spain has shown that solar energy plays a vital role in the future of renewable energy. Spain has also become one of the leading counties in terms of applications, expertise, and development of new technologies. Solar PV is being implemented at a large scale, ranging from $10 \mathrm{MW}$ to $30 \mathrm{MW}$ [10].

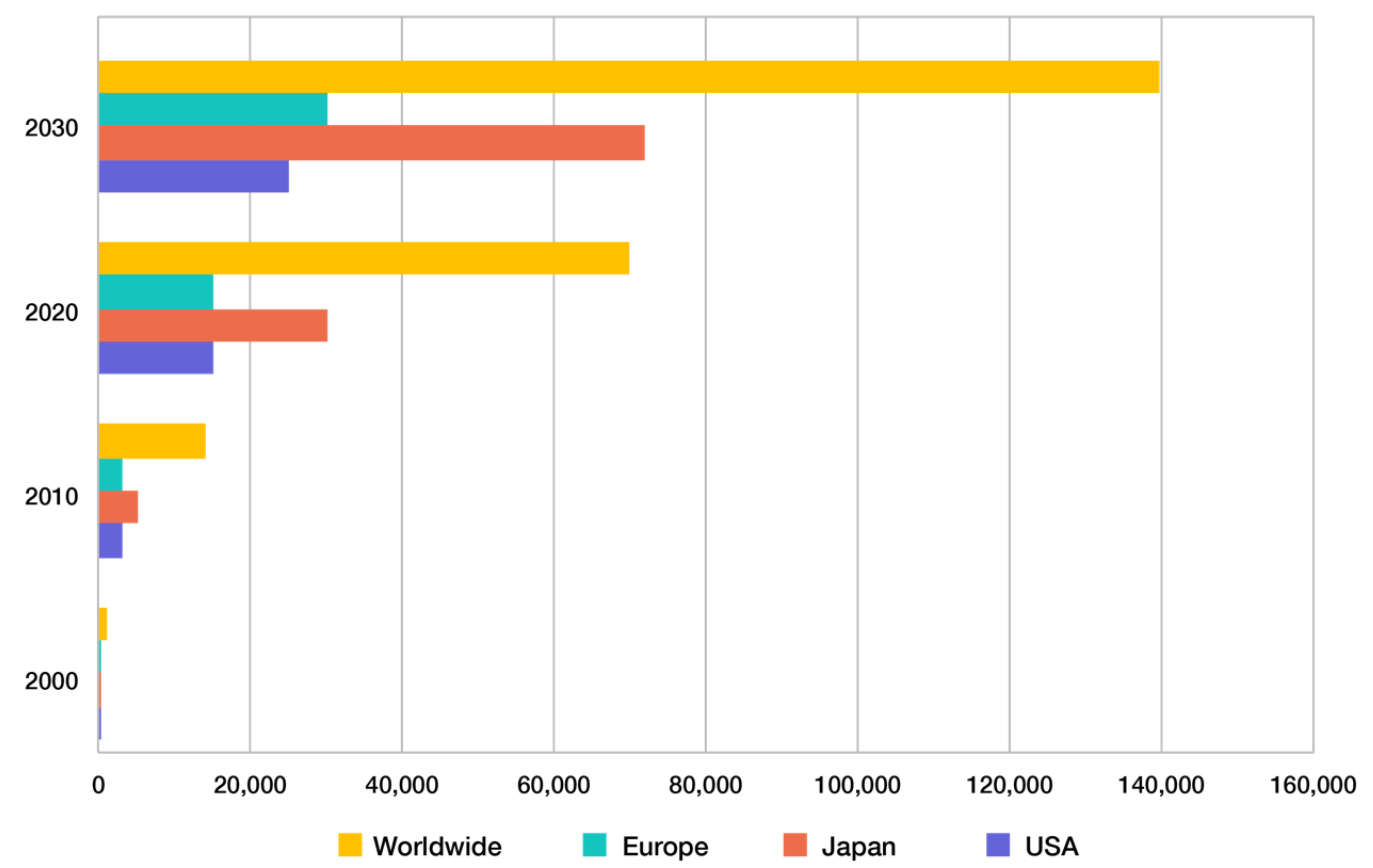

Figure 12. The expected development and installation of solar photovoltaic electricity (megawatts unit).

For some countries in Asia, the potential of solar energy for generating electricity is very high. The cost of PV power generation will likely decrease supported by energy policies, enabling solar power generation to be applied at large scale with huge production capacity [81]. Pakistan is pursuing potential solar energy to provide electricity for agriculture. This is an excellent and sustainable energy source that interests the Pakistan government. The country's location makes it capable of sun irradiation of $200-250 \mathrm{~W} / \mathrm{m}^{2}$ of average global irradiation, or $6840-8282 \mathrm{MJ} / \mathrm{m}^{2}$ [82].

In Malaysia, the rough estimation of RE potential has been demonstrated in the long term. Malaysia's hydropower and solar PV production are undertaken without RE achieving the highest potential due to its geographic features of large rivers, huge amounts of sunlight, and being a tropical country, which are advantages for the installation of PV /FPV panel plants (Figure 13) [83].

Figure 13 shows the photovoltaic power potential in the world [84]. In the world, the value of $2.100 \mathrm{kWh} / \mathrm{kWp}$ is a noteworthy breakeven point annually. A world map with the annual value of photovoltaic power potential in $\mathrm{kWh}$ per $\mathrm{kWp}$ is shown below. Figure 14 shows that only the brown areas reach this value [84].

\subsection{The Future of Solar Energy Used in Aquaculture}

Use of renewable energy for cultivating aquatic organisms is an excellent innovation in sustainable aquaculture. It is a proven eco-friendly innovation for enhancing aquaculture without damaging natural aquatic ecosystems. In addition, the cost of production can be directly reduced by producing more energy at scale and at cheaper cost. Efficiently 
produced energy can be used for aeration, feed dissension, water pumping, and light sources [11]. The demand for energy for aquaculture will increase from 4600 million GJ to 10.700 million GJ because of the high demand for fish need by 2050 [85].

Potential (MW)

25,000

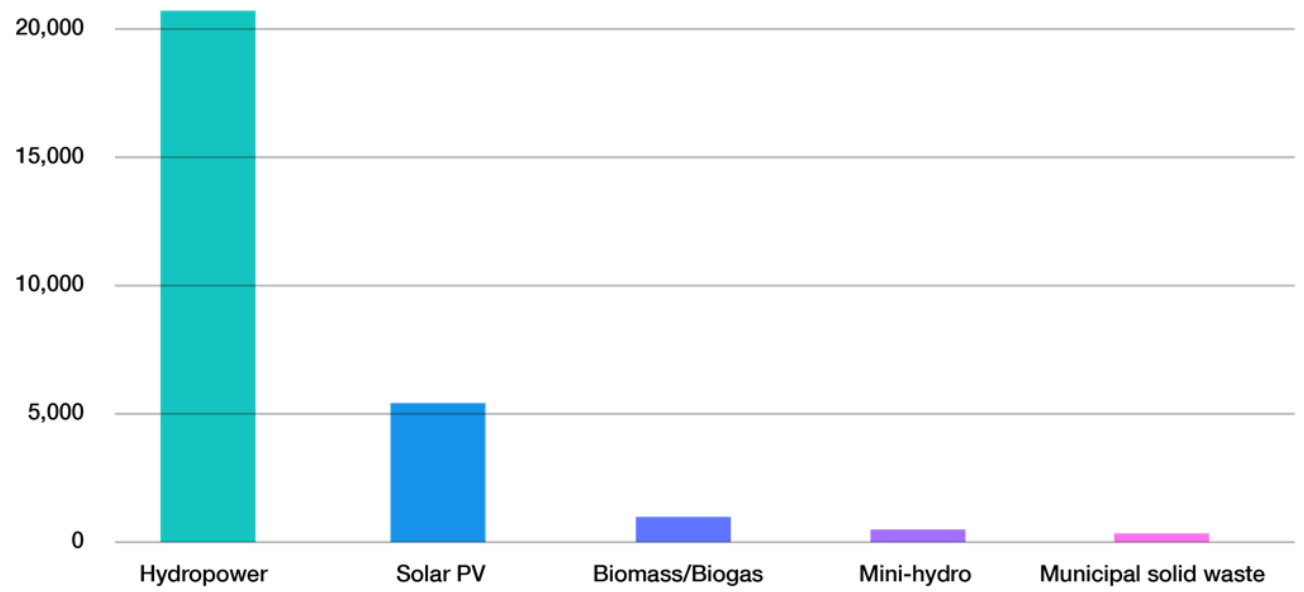

Figure 13. Renewable energy potential in Malaysia.

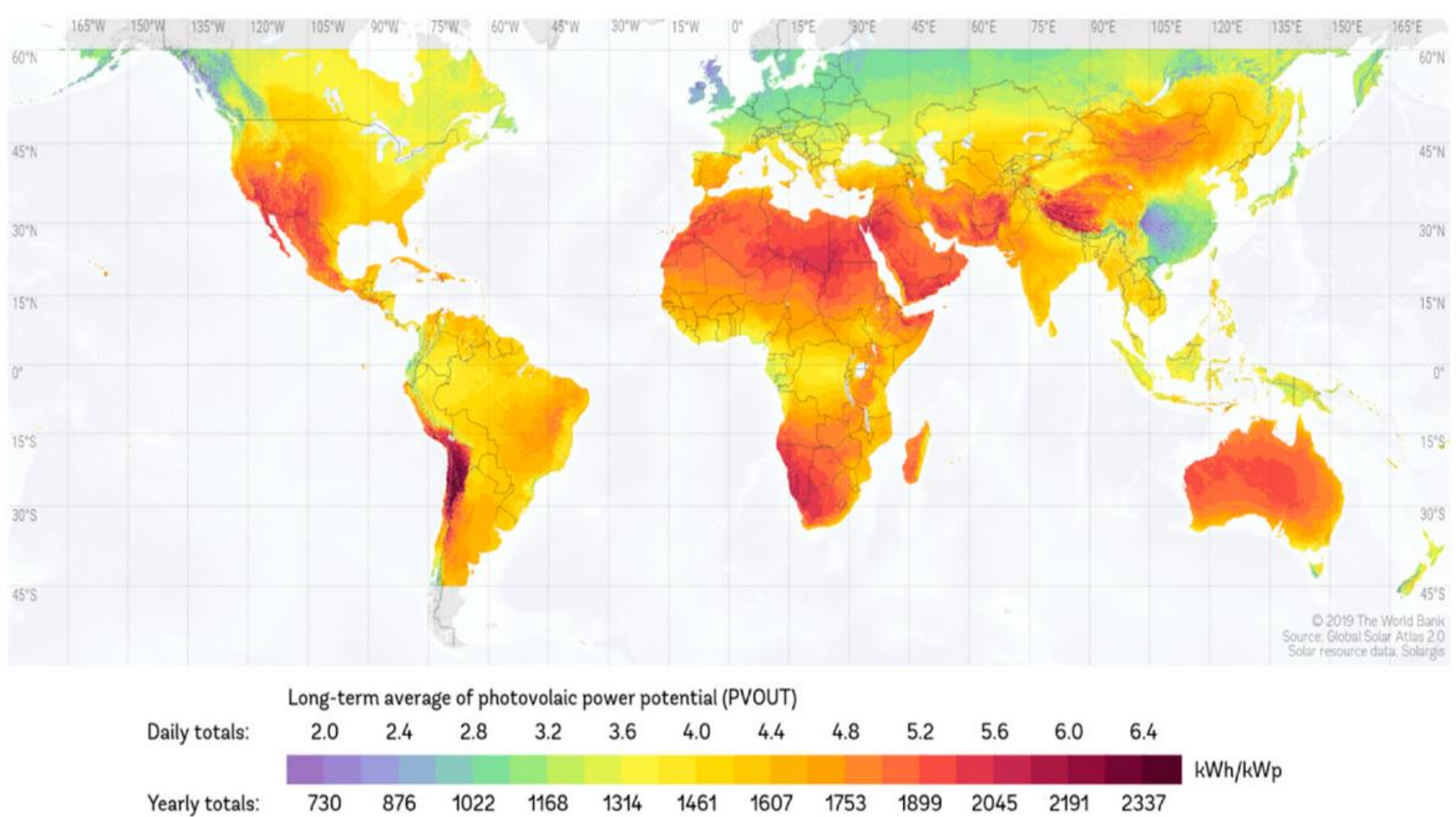

Figure 14. Photovoltaic power potential in the world.

FPV (floating photovoltaic) systems are built out of same PV panels as land-based PV systems, but the modules float in water, mainly suspended on floats and tethered to land. An FPV plant can be installed in different water bodies inland (e.g., dams/reservoirs; lakes, lagoons, canals) as well as offshore (ocean) [86]. The importance of FPV is predicted to rise even more with potential offshore ocean applications besides fish farming, including water 
desalination, shipping, data-center cooling, and even hydrogen production [84]. This is a future sustainable energy that will provide electricity for open sea culture systems in the aquaculture industry.

The main motivation of FPV is land premium, especially for agriculture. However, for future-oriented concepts, this will be applied not only in freshwater synthetic reservoirs but also in marine and large lacustrine sites. The World Bank [87] estimates a potential of 400 gigawatts (GW) to be produced from FPV worldwide. FPV has been installed with a capacity of 1100 Megawatts (MW), with China leading the global market followed by Japan and South Korea [88] as of mid-2018.

A project conducted in Singapore's open seas is an example (Figure 15). Singapore has already launched the world's largest floating PV which has been tested on the Tengeh reservoir in Tuas with a total installed capacity of around $1 \mathrm{MWp}$. The goal of this test was to study the technical, economic, and environmental feasibility of conducting large-scale floating PV systems, usually mounted on a floating pontoon structure [89].

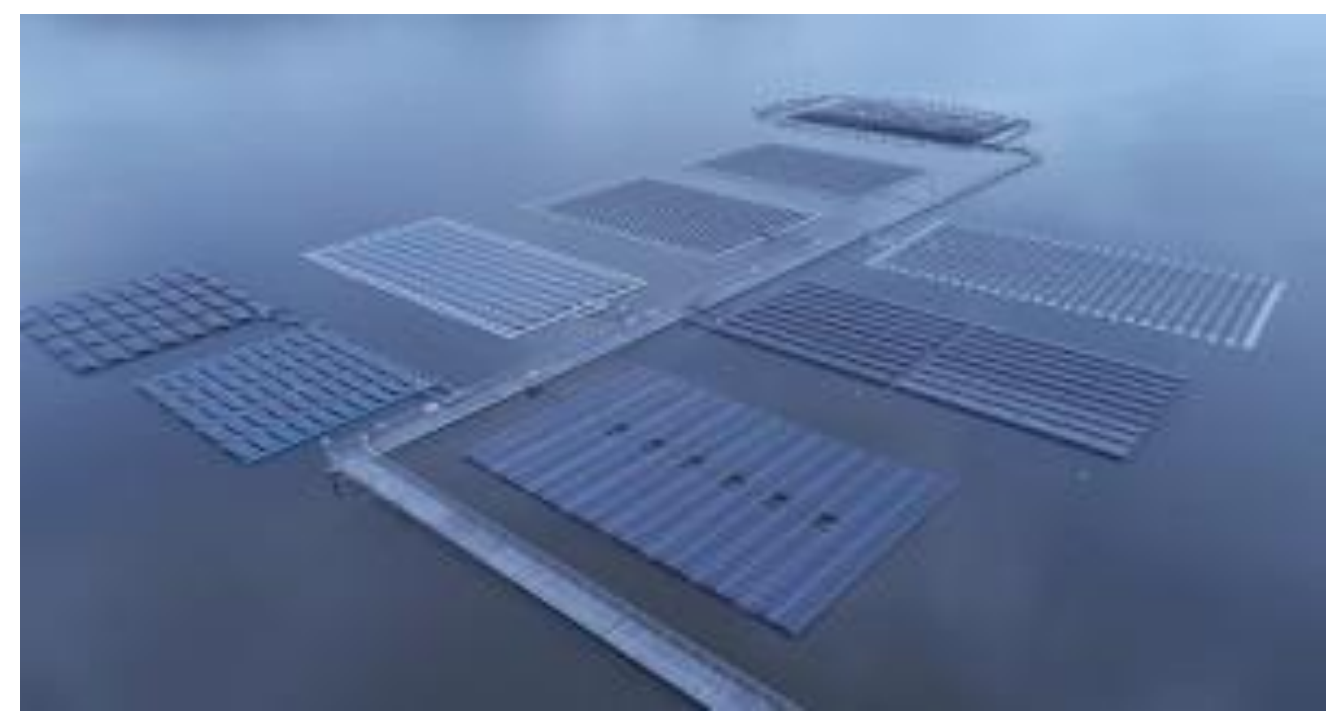

Figure 15. Floating PV system in Singapore.

At the same time as fish aquaculture continues to grow and intensify worldwide, photovoltaic-based aquaculture can also exploit the potential approach outlined here. Solar power plants generate electricity that supply most aquaculture activities, for instance aeration systems, water pumps, and water purification systems, therefore sustaining the aquaculture [86].

There are several models that apply solar power to provide energy for different purposes in aquaculture and agriculture, such as electricity for evaporating fishponds to make fresh water, a process called desalination, for watering plants. This model is designed for land but can be adapted to operate on the ocean. There are some sample models that can be expanded and applied at scale in the near future; see Figure 15.

Meanwhile, Figure 16 shows a design as a sample system that includes three main parts or units as follows: (1) a PV panel to absorb solar irradiation to transfer into electricity; (2) a device for desalination; (3) an agriculture farm that can be irrigated by water after desalination. The obtained fresh water can be used to water target plants. It is a smart system that can be installed on an island. Another example is a culture system deployed for milkfish ponds [90]. This is a good example of applying FPV in aquaculture to overcome the disadvantages of installing a PV system. However, they suggest that it should be installed over $60 \%$ of the pond area to ensure optimal environmental conditions in the culture system; see Figure 17 [91]. 


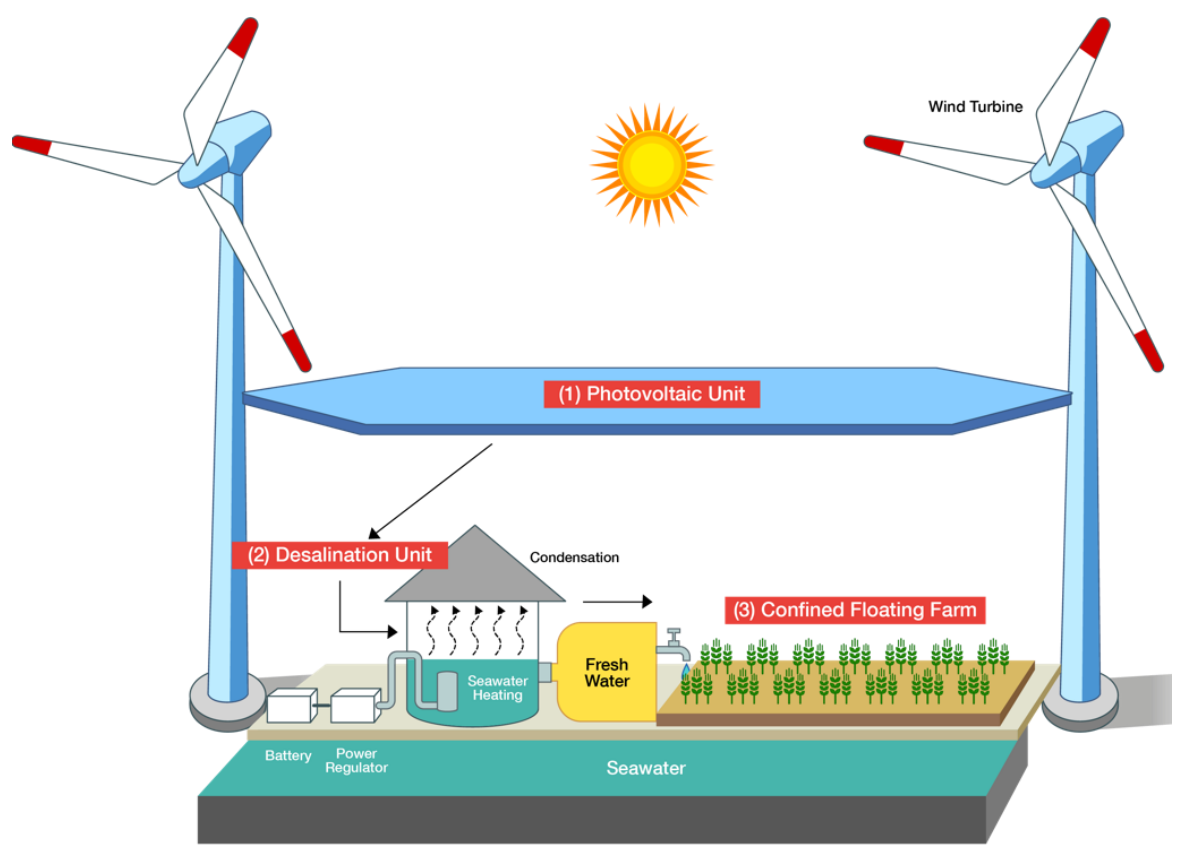

Figure 16. The desalination system for aquaculture/agriculture.

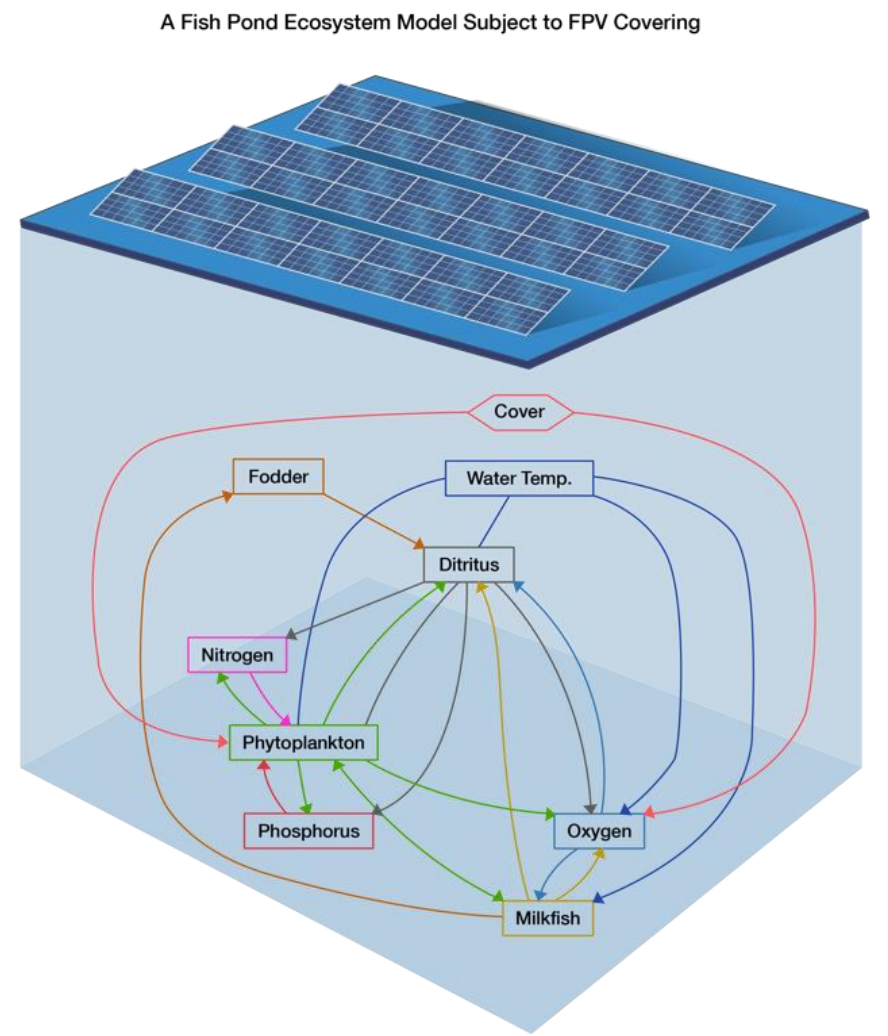

Figure 17. Floating photovoltaic in a milkfish pond.

\section{Conclusions}

Many projects using solar energy for aquaculture are increasingly pursued in several countries because of its benefits. Solar power has the most potential of renewable resources. It is sustainable and hard to change by the weather or the season. It can be generated by two main kinds of technologies - solar thermal and solar PV—for several implementations. It is noted that solar energy is not just relatively simpler but also much more eco-friendly 
compared to fossil fuel or coal power generation. With the global demand for energy consumption increasing yearly, switching to renewable solar energy is a viable solution.

Solar energy for aquaculture is a potential renewable energy source of the future. It has already provided sustainable electricity. Many countries have looked to sustainable energy alternatives beyond non-renewable resources, in particular solar PV technologies including PV, FPV, and CSP. It has excellent and promising potential for improving aquaculture systems located on the ocean and islands off the national grid. Electricity, which is generated from a PV solar panel, can be supplied for fish, horse mackerel, sea cucumbers, shrimp farms, floating and cage activities including aerators, water pumps, and other devices (light, fridge, and fan). This is an effective and sustainable solution to decrease the cost of production in aquaculture in different countries in the world such as China, Taiwan, Indonesia, Malaysia, Canada, Bangladesh, and Vietnam. On the other hand, the site of aquaculture is often off the national grid, e.g., for cage systems offshore or a long distance from the national grid. Therefore, it is necessary to use PV solar power in aquaculture.

In the future, energy prices will further decrease thanks to increased production of renewable energy components at scale. The supply and availability of components on the market is essential, so various components and options are very sensitive to energy prices. However, by decreasing the cost of solar panels, it will be possible to expand the potentially usable fields across many countries.

Funding: This work was supported by a research grant from Seoul Women's University (2021-0148).

Conflicts of Interest: The authors declare no conflict of interest.

\author{
Abbreviations \\ OECD Organisation for Economic Co-operation and Development \\ NOAA National Oceanic and Atmospheric Administration \\ CSP Concentrated Solar Power \\ PV Photovoltaic \\ COE Cost of Energy \\ PEM Proton-Exchange Membrane
}

\title{
References
}

1. Bostock, J.; McAndrew, B.; Richards, R.; Jauncey, K.; Telfer, T.; Lorenzen, K.; Little, D.; Ross, L.; Handisyde, N.; Gatward, I.; et al. Aquaculture: Global status and trends. Philos. Trans. R. Soc. B 2010, 365, 2897-2912. [CrossRef]

2. Available online: //www.marketwatch.com/press-release/global-aquaculture-market-2021-covid-19-impact-key-playerstrends-sales-supply-analysis-and-forecast-2027-2021-02-19?tesla=y (accessed on 30 June 2021).

3. FAO. Sustainability on Action World Fisheries and Aquaculture; Food and Agriculture Organization of the United Nations: Rome, Italy, 2020.

4. Tyedmers, P.; Pelletier, N. Biophysical accounting in aquaculture: Insights from current practice and the need for methodological development. In Comparative Assessment of the Environmental Costs of Aquaculture and Other Food Production Sectors: Methods for Meaningful Comparisons; FAO/WFT Expert Workshop; FAO Fisheries Proc. No. 10; Food and Agriculture Organization of the United Nations: Rome, Italy, 2007; pp. 229-241.

5. Kim, Y.W. Selection of Energy Systems in Aquaculture through a Decision Support Tool Considering Economic and Environmental Sustainability. Ph.D. Thesis, University of South Florida, Tampa, FL, USA, 2018.

6. LiVecchi, A.; Copping, A.; Jenne, D.; Gorton, A.; Preus, R.; Gill, G.; Robichaud, R.; Green, R.; Geerlofs, S.; Gore, S.; et al. Powering the Blue Economy; Exploring Opportunities for Marine Renewable Energy in Maritime Markets; U.S. Department of Energy, Office of Energy Efficiency and Renewable Energy: Washington, DC, USA, 2019.

7. International Energy Agency. World Energy Outlook; International Energy Agency: Paris, France, 2012.

8. International Energy Agency. World Energy Outlook Special Report 2015: Energy and Climate Change; International Energy Agency: Paris, France, 2015.

9. National Oceanic and Atmospheric Administration. National Centers for Environmental Information, State of the Climate: Global Analysis. Available online: http:/ / www.ncdc.noaa.gov/sotc/global/201507 (accessed on 30 June 2021).

10. Solangi, K.H.; Islamb, M.R.; Saidur, R.; Rahimb, N.A.; Fayaz, H. A review on global solar energy policy. Renew. Sust. Energ. Rev. 2011, 15, 2149-2163. [CrossRef] 
11. Bharathi, S.; Cheryl, A.; Uma, A.; Ahilan, B.; Aanand, S.; Somu Sunder Lingam, R. Application of renewable energy in aquaculture. Aqua Int. 2019, 48-54. Available online: https://www.researchgate.net/publication/331716127_Application_of_Renewable_ Energy_in_Aquaculture_Application_of_Renewable_Energy_in_Aquaculture (accessed on 30 June 2021).

12. Salam, M.A.; Khan, S.A. Transition towards sustainable energy production-A review of the progress for solar energy in Saudi Arabia. Energy Explor. Exploit. 2018, 36, 3-27. [CrossRef]

13. IRENA. Renewable Power Generation Costs in 2019; International Renewable Energy Agency: Abu Dhabi, United Arab Emirates, 2020.

14. Edenhofer, O.; Pichs-Madruga, R.; Sokona, Y.; Seyboth, K.; Matschoss, P.; Kadner, S. IPCC Special Report on Renewable Energy Sources and Climate Change Mitigation; Working Group III of the Intergovernmental Panel on Climate Change: Cambridge, UK, 2011.

15. Ioakeimidis, C.; Polatidis, H.; Haralambopoulos, D. Use of renewable energy in aquaculture: An energy audit case-study analysis. Glob. NEST J. 2013, 15, 82-294.

16. Setiawan, A.; Setiawan, A.A. Community development in solar energy utilization to support fish farming in Sendangsari village. Energy Procedia 2013, 32, 39-46. [CrossRef]

17. Pringle, A.M.; Handler, R.M.; Pearce, J.M. Aquavoltaics: Synergies for dual use of water area for solar photovoltaic electricity generation and aquaculture. Renew. Sustain. Energy Rev. 2017, 80, 572-584. [CrossRef]

18. Kim, Y.; Zhang, Q. Modeling of energy intensity in aquaculture: Future energy use of global aquaculture. SDRP J. Aquac. Fish. Fish Sci. 2018, 2, 60-89.

19. Sahu, A.; Yadav, N.; Sudhakar, K. Floating photovoltaic power plant: A review. Renew. Sustain. Energy Rev. 2016, 66, 815-824. [CrossRef]

20. US Department of Energy (USDE). Concentrating Solar Power. Available online: http://www1.eere.energy.gov/solar/sunshot/ csp.html (accessed on 30 June 2021).

21. Corral, N.; Anrique, N.; Fernandes, D.; Parrado, C.; Cáceres, G. Power, placement and LEC evaluation to install CSP plants in northern Chile. Renew. Sustain. Energy Rev. 2012, 16, 6678-6685. [CrossRef]

22. Bosetti, V.; Catenacci, M.; Fiorese, G.; Verdolini, E. The future prospect of PV and CSP solar technologies: An expert elicitation survey. Energy Policy 2012, 49, 308-317. [CrossRef]

23. Py, X.; Azoumah, Y.; Olives, R. Concentrated solar power: Current technologies, major innovative issues and applicability to West African countries. Renew. Sustain. Energy Rev. 2013, 18, 306-315. [CrossRef]

24. Applebaum, J.; Mozes, D.; Steiner, A.; Segal, I.; Barak, M.; Reuss, M.; Roth, P. Progress in Photovoltaics: Research and application. Photovoltaics 2001, 9, 275-301.

25. Campen, B.V.; Guidi, D.; Best, G. Solar Photovoltaics for Sustainable Agriculture and Rural Development; Environment and Natural Resources Working Paper No. 2; FAO: Rome, Italy, 2000.

26. Tanveer, M.; Mayilsamy, S. A conceptual approach for development of solar powered aeration system in aquaculture farms. Int. J. Environ. Sci. Technol. 2016, 5, 2921-2925.

27. Appelbaum, J.; Mozes, D.; Steiner, A.; Segal, I.; Bark, M.; Reuss, M.; Roth, P. Aeration of fish-ponds by photovoltaic power. Prog. Photovolt. 2001, 9, 295-301. [CrossRef]

28. Satriadi, A.B. Designing Windmill as a Driver of Shrimp Pond Aerator. Bachelor's Thesis, Department of Engineering Physics, Faculty of Engineering, Gadjah Mada University, Yogyakarta, Indonesia, 2010.

29. Ghoniem, A.A. Design optimization of photovoltaic powered water pumping system. Energy Convers. Manag. 2006, 47, 1449-1463. [CrossRef]

30. Meah, K.; Fletcher, S.; Ula, S. Solar photovoltaic water pumping for remote location. Renew. Sustain. Energy Rev. 2008, 12, 472-487. [CrossRef]

31. Sadat, S.A.; Faraji, J.; Babaei, M.; Ketabi, A. Techno-Economical Study of Two Hybrid Power Systems for a Remote Village in Iran by Homer Software; Shahid Rajae Teacher Training University: Tehran, Iran, 2011.

32. Cao, L.; Diana, J.S.; Keoleian, G.A. Role of life cycle assessment in sustainable aquaculture. Rev. Aquacult. 2013, 5, 61-71. [CrossRef]

33. Nash, C.E. The History of Aquaculture; Wiley-Blackwell: Ames, IA, USA, 2011.

34. Toner, D.; Mathies, M. The Potential for Renewable Energy Usage in Aquaculture. 2002. Aquaculture Initiative. Available online: http:/ / www.aquacultureinitiative.eu/Renewable\%20Energy\%20Report.pdf (accessed on 30 June 2021).

35. Aquatera. Renewable Power Generation on Aquaculture Sites. Scottish Aquaculture Research Forum 2014. Available online: http:/ / www.sarf.org.uk/cms-assets/documents/152961--230407.sarf093.pdf (accessed on 30 June 2021).

36. Fiander, L.; Graham, M.; Murray, H.; Boileau, R. Land based multi-trophic aquaculture research at the wave energy research center. In Proceedings of the Oceans, St. John's, NL, Canada, 14-19 September 2014; pp. 1-5.

37. Ayer, N.W.; Tyedmers, P.H. Assessing alternative aquaculture technologies: Life cycle assessment of salmonid culture systems in Canada. J. Clean. Prod. 2009, 17, 362-373. [CrossRef]

38. Pelletier, N.; Tyedmers, P.; Sonesson, U.; Scholz, A.; Ziegler, F. Not all salmon are created equal: Life cycle assessment (LCA) of global salmon farming systems. Environ. Sci. Technol. 2009, 43, 8730-8736. [CrossRef] [PubMed]

39. Pelletier, N.; Tyedmers, P. Life Cycle Assessment of frozen tilapia fillets from Indonesian lake-based and pond-based intensive aquaculture systems. J. Ind. Ecol. 2010, 14, 467-481. [CrossRef] 
40. Heeb, J.; Wyss, P. Tropical polyculture production with the integrated "Tropenhaus" concept-Case study in Switzerland. In Sustaina Aqua Handbook-A Handbook of Sustainable Aquaculture; Váradi, L., Bardócz, T., Oberdieck, A., Eds.; Bremerhaven, Germany, 2017; pp. 95-98. Available online: https://haki.naik.hu/sites/default/files/uploads/2018-09/sustainaqua_handbook_en.pdf (accessed on 30 June 2021).

41. Costa-Pierce, B. Sustainable ecological aquaculture systems: The need for a new social contract for aquaculture development. Mar. Technol. Soc. J. 2010, 44, 88-112. [CrossRef]

42. Eding, E.; Kamstra, A. Netherlands farms tune recirculation systems to production of varied species. Glob. Aquac. Advocate 2002, $5,52-55$.

43. Aubin, J.; Papatryphon, E.; van der Werf, H.M.G.; Chatzifotis, S. Assessment of the environmental impact of carnivorous finfish production systems using life cycle assessment. J. Clean. Prod. 2009, 17, 354-361. [CrossRef]

44. Gál, D.; Pekár, F.; Kerepeczki, E.; Váradi, L. Experiments on the operation of a combined aquaculture-algae system. Aquacult. Int. 2007, 15, 173-180. [CrossRef]

45. Cao, L.; Diana, J.S.; Keoleian, G.A.; Lai, Q. Life cycle assessment of Chinese shrimp farming systems targeted for export and domestic sales. Environ. Sci. Technol. 2011, 45, 6531-6538. [CrossRef]

46. Iribarren, D. Life Cycle Assessment of Mussel and Turbot Aquaculture: Application and Insights. Ph.D. Thesis, Universidade de Santiago de Compostela, Santiago de Compostela, Spain, 2010.

47. Winther, U.; Ziegler, F.; Hognes, E.S.; Emanuelsson, A.; Sund, V. Carbon Footprint and Energy Use of Norwegian Seafood Products; SINTEF Fisheries and aquaculture Report No. 2009; SINTEF: Trondheim, Norway, 2009.

48. Meyhoff Fry, J. Carbon Footprint of Scottish Suspended Mussels and Intertidal Oysters; SARF078; Scottish Aquaculture Research Forum (SARF): Pitlochry, Scotland, UK, 2011.

49. Kim, Y.; Wang, M.; Kinyua, M.; Cools, C.; Zhang, Q.; Ergas, S.J. Alternative Energy Sources for Florida Aquaculture Systems Final Report; Department of Civil and Environmental Engineering, University of South Florida: Tampa, FL, USA, 2015.

50. Boxman, S.E.; Zhang, Q.; Bailey, D.; Trotz, M.A. Life cycle assessment of a commercial-scale freshwater aquaponics system. Environ. Eng. Sci. 2017, 34, 299-311. [CrossRef]

51. Al-Saidi, M.; Lahham, N. Solar energy farming as a development innovation for vulnerable water basins. Dev. Pract. 2019, 29, 619-634. [CrossRef]

52. Huh, J.-H. PLC-based design of monitoring system for ICT-integrated vertical fish farm. Hum-Cent. Comput. Inf. Sci. 2017, 7, 1-19. [CrossRef]

53. UNHCR. UNHCR Launches Sustainable Energy Strategy, Strengthens Climate Action. 24 October 2019. Available online: https: / / www.unhcr.org/news/press/2019/10/5db156d64/unhcr-launchessustainable-energy-strategy-strengthens-climateaction.html (accessed on 30 June 2021).

54. Prasetyaningsari, I.; Setiawan, A.; Setiawan, A.A. Design optimization of solar powered aeration system for fish pond in Sleman Regency, Yogyakarta by HOMER software. Energy Procedia 2013, 32, 90-98. [CrossRef]

55. Liu, X.; Xu, H.; Ma, Z.; Zhang, Y.; Tian, C.; Cheng, G. Design and application of a solar mobile pond aquaculture water quality-regulation machine based in Bream Pond aquaculture. PLoS ONE 2016, 11, e0146637. [CrossRef]

56. Hendarti, R.; Wangidjaja, W.; Septiafani, L.G. A study of solar energy for an aquaculture in Jakarta. In Proceedings of the 2nd International Conference on Eco Engineering Development 2018 (ICEED 2018), Tangerang, Indonesia, 5-6 September 2018.

57. Kirihara, S.; Shida, T.; Kubota, T.; Honda, A.; Itaka, K.; Guan, G.; Ioka, S. Research on Utilization of Renewable Energy for Aquaculture of Horse Mackerel and Sea Cucumber in Fishing Ports. Grand Renewable Energy 2018 Proceedings June 2018 Pacifico Yokohama. In Proceedings of the Japan Council for Renewable Energy, Yokohama, Japan, 17-22 June 2018.

58. Nguyen, N.T.; Matsuhashia, R.; Vo, T.T.B.C. A sustainable energy model for shrimp farms in the Mekong Delta. Energy Procedia 2019, 157, 926-993.

59. Nguyen, N.T.; Matsuhashi, R. An optimal design on sustainable energy systems for shrimp farms. IEEE Power Energy Soc. Sect. 2019, 7, 165543-165558. [CrossRef]

60. Tous-Zamora, D.; de la Rosa-Sánchez, F.; Sánchez-Teba, E.M.; Cordero-Tous, M.; Ruiz-Campos, R. Design of an aquaponic system run on solar power for a family business in Chad. Eur. J. Manag. Bus. Econ. 2019, 9, 39-48.

61. Available online: https://gogetfunding.com/solar-cell-recirculatied-aquaculture-aquaculture-system (accessed on 30 June 2021 ).

62. Babiyola, D.; Thamarai Selva, J. A Conceptual approach for development of solar power supply in aquaculture farm using net meter system in Nagapattinam Area. Emp. J. Appl. Sci. Res. 2019, 5, 1-7.

63. Cornejo-Ponce, L.; Vilca-Salinas, P.; Lienqueo-Aburto, H.; Arenas, M.J.; Pepe-Victoriano, R.; Carpio, E.; Rodríguez, J. Integrated Aquaculture Recirculation System (IARS) Supported by Solar Energy as a Circular Economy Alternative for Resilient Communities in Arid/Semi-Arid Zones in Southern South America: A Case Study in the Camarones Town. Water 2020, 12, 3469. [CrossRef]

64. Aquaculture 4.0 with Small Technologies. Available online: https:/ / www.innovationnewsnetwork.com/aquaculture-4--0-withsmalle-technologies/3886/ (accessed on 30 June 2021).

65. Available online: https://www.blue21.nl/massive-photovoltaic-power-station-built-on-fishery-in-is-china-now-operational/ (accessed on 30 June 2021).

66. Available online: https:/ / focustaiwan.tw/sci-tech/202011060024 (accessed on 30 June 2021).

67. Available online: https://www.rastechmagazine.com/solar-energy-gives-aquaculture-a-boost-in-shrimps-project (accessed on 30 June 2021). 
68. Available online: http:/ / reeep.sreda.gov.bd/interventions/renewable-energy/solar-aquaculture.html (accessed on 30 June 2021).

69. Introducing Solar Energy in Egyptian Aquaculture/Fish Consulting Group. Available online: https:/ fishconsult.org/?p=14881 (accessed on 30 June 2021).

70. Aman, M.M.; Solangi, K.H.; Hossain, M.S.; Badarudin, A.; Jasmon, G.B.; Mokhlis, H.; Bakar, A.H.A.; Kazi, S.N. A review of Safety, Health and Environmental (SHE) issues of solar energy system. Renew. Sustain. Energy Rev. 2015, 41, 1190-1204. [CrossRef]

71. Mahesh, A.; Shoba Jasmin, K.S. Role of renewable energy investment in India: An alternative to CO2 mitigation. Renew. Sustain. Energy Rev. 2013, 26, 414-424. [CrossRef]

72. Liu, S.Y.; Perng, Y.H.; Ho, Y.F. The effect of renewable energy application on Taiwan buildings: What are the challenges and strategies for solar energy exploitation? Renew. Sustain. Energy Rev. 2013, 28, 92-106. [CrossRef]

73. International Energy Agency (IEA). Technology Roadmap: Solar Photovoltaic Energy. 2010. Available online: http:/ /www.iea. org/publications/freepublications/publication/pv_roadmap.pdf (accessed on 30 June 2021).

74. Turney, D.; Fthenakis, V. Environmental impacts from the installation and operation of large-scale solar power plants. Renew. Sustain. Energy Rev. 2011, 15, 3261-3270. [CrossRef]

75. Thavasi, V.; Ramakrishna, S. Asia energy mixes from socio-economic and environmental perspectives. Energy Policy 2009, 37, 4240-4250. [CrossRef]

76. REN21. Renewable Energy Policy Network for the 21st Century; Report; Renewable Energy Policy Network for the 21st Century: Paris, France, 2009.

77. Creutzig, F.; Agoston, P.; Goldschmidt, J.C.; Luderer, G.; Nemet, G.; Pietzcker, R.C. The underestimated potential of solar energy to mitigate climate change. Nat. Energy 2017, 2, 17140. [CrossRef]

78. USDE. Study: Solar Power Could Provide 10\% of U.S. Electricity by 2025. Available online: http://apps1.eere.energy.gov/news/ newsdetail.cfm/newsid=11835 (accessed on 30 June 2021).

79. Wiginton, L.K.; Nguyen, H.T.; Pearce, J.M. Quantifying rooftop solar photovoltaic potential for regional renewable energy policy. Comput. Environ. Urban. Syst. 2010, 34, 345-357. [CrossRef]

80. Branker, K.; Pearce, J.M. Financial return for government support of largescale thin-film solar photovoltaic manufacturing in Canada. Energy Policy 2010, 38, 4291-4303. [CrossRef]

81. Wang, Q. Effective policies for renewable energy-the example of China's wind power-lessons for China's photovoltaic power. Renew. Sustain. Energy Rev. 2010, 14, 702-712. [CrossRef]

82. Ashraf, C.M.; Raza, R.; Hayat, S.A. Renewable energy technologies in Pakistan: Prospects and challenges. Renew. Sustain. Energy Rev. 2009, 13, 1657-1662. [CrossRef]

83. Oh, T.H.; Pang, S.Y.; Chua, S.C. Energy policy and alternative energy in Malaysia: Issues and challenges for sustainable growth. Renew. Sustain. Energy Rev. 2010, 14, 1241-1252. [CrossRef]

84. ESMAP. Photovoltaic Power Potential in the World; World Bank: Washington, DC, USA, 2019.

85. Mungkung, R.; de Haes, H.U.; Clift, R. Potentials and limitations of life cycle assessment in setting ecolabelling criteria: A case study of Thai shrimp aquaculture product. Int. J. Life Cycle Assess. 2006, 11, 55-59. [CrossRef]

86. Abid, M.; Abid, Z.; Sagin, J.; Murtaza, R.; Sarbassov, D.; Shabbir, M. Prospects of floating photovoltaic technology and its implementation in Central and South Asian Countries. Int. J. Environ. Sci. Technol. 2018, 16, 1-9. [CrossRef]

87. The World Bank; ESMAP; SERIS. Where Sun Meets Water: Floating Solar Market Report, Executive Summary; World Bank: Washington, DC, USA, 2019.

88. Singhal, D.; Suresh, S.; Arora, S.; Singhvi, S.; Rustagi, V. Floating Solar-Opportunities and Way Ahead; Bridge of India Report; Bridge of India: Gurgaon, India, 2018; pp. 1-12.

89. Available online: https://www.solarnovus.com/researchers-study-feasibility-of-floating-photovoltaics-in-open-sea-conditions_ N11617.html (accessed on 30 June 2021).

90. Moustafa, K. Toward Future Photovoltaic-Based Agriculture in Sea. Trends Biotechnol. 2016, 34, 257-259. [CrossRef]

91. Château, P.A.; Wunderlich, R.F.; Wang, T.W.; Lai, H.T.; Chen, C.C.; Chang, F.J. Mathematical modeling suggests high potential for the deployment of floating photovoltaic on fish ponds. Sci. Total. Environ. 2019, 687, 654-666. [CrossRef] [PubMed] 